\title{
Developmental Changes in the Expression of Chemokine Receptor CCR1 in the Rat Cerebellum
}

\author{
RITA MARIE COWELL ${ }^{1}$ AND FAYE SARAH SILVERSTEIN ${ }^{1,2 *}$ \\ ${ }^{1}$ Neuroscience Program, University of Michigan, Ann Arbor, Michigan 48109 \\ ${ }^{2}$ Departments of Pediatrics and Neurology, University of Michigan, \\ Ann Arbor, Michigan 48109
}

\begin{abstract}
Chemokines are small, soluble proteins that regulate leukocyte migration, adhesion, and proliferation. Recent evidence suggests that chemokine receptors are expressed in the central nervous system and that their functions extend beyond their roles in inflammation. Specific chemokines and their receptors are implicated in cerebellar development. In this study, we evaluated the expression of $\beta$-chemokine receptor CCR1 in the immature and adult rat cerebellum and report striking developmental changes in CCR1 expression. Reverse transcriptase polymerase chain reaction assays of cerebellum revealed moderate increases in CCR1 mRNA expression from postnatal day (P) 3 to adulthood. Light and confocal microscopy were used to evaluate developmental changes in the neuroanatomical and cell-specific distribution of CCR1 immunoreactivity. CCR1 immunoreactivity was detected as early as P3 and peaked between P7 and P21. The predominant CCR1-immunoreactive neuronal cell types included granule cells of the internal granular layer, Purkinje cells, Golgi cells, and molecular layer interneurons; Bergmann glia, astrocytes, and resting microglia also expressed CCR1. In contrast, granule cells in the external germinal layer, descending granule cells, and activated microglia rarely expressed CCR1. We also evaluated the expression of the CCR1 ligand macrophage inflammatory protein-1 $\alpha$ (MIP-1 $\alpha / C C L 3)$. Two cell populations expressed MIP-1 $\alpha$ : physiologically activated microglia in white matter (P7-P14) and Purkinje cells (P7-adult). MIP-1 $\alpha$-positive cells were frequently located near the processes and cell bodies of CCR1-immunoreactive cells, during times of neuronal and glial maturation (second and third postnatal weeks). These findings provide support for the hypothesis that CCR1 plays a role in postnatal cerebellar development. J. Comp. Neurol. 457:7-23, 2003.

() 2003 Wiley-Liss, Inc.
\end{abstract}

Indexing terms: macrophage inflammatory protein $1 \alpha$; granule cell; Bergmann glia; Purkinje cell; basket cell

Chemokines constitute a group of small $(8-13 \mathrm{kD})$, soluble, structurally related proteins that attract leukocytes to sites of infection or injury through interactions with G-protein-coupled receptors (Locati and Murphy, 1999). Chemokines are classified as CC ( $\beta$-chemokine), CXC $(\alpha-$ chemokine), $\mathrm{XC}$, or $\mathrm{CX}_{3} \mathrm{C}$ group members, based on the sequence of the cysteine motif near their amino termini. There is growing recognition that chemokines play diverse and complex roles in central nervous system development and disease (Asensio and Campbell, 1999; Mennicken et al., 1999). Recent work has demonstrated that neurons, astrocytes, and microglia can express multiple chemokines and chemokine receptors in vitro and in vivo (Hesselgesser and Horuk, 1999; Mennicken et al., 1999); the functionality of these receptors has been characterized in vitro. Chemokines can regulate neurotransmission (Giovannelli et al., 1998; Klein et al., 1999; Limatola et al.,

Grant sponsor: American Heart Association; Grant numbers: 0110233Z (R.M.C.); US PHS NS 35059 (F.S.S.).

*Correspondence to: Faye Sarah Silverstein, 8301 MSRB III, 1150 W. Medical Center Drive, Ann Arbor, MI 48109. E-mail: fsilvers@umich.edu Received 23 May 2002; Revised 8 August 2002; Accepted 13 September 2002

DOI 10.1002/cne.10554

Published online the week of January 13, 2003 in Wiley InterScience (www.interscience.wiley.com). 
2000) and neuronal/astrocytic migration (Hesselgesser et al., 1997; Tanabe et al., 1997) and survival (Hesselgesser et al., 1998; Meucci et al., 1998, 2000; Kaul and Lipton, 1999; Bakhiet et al., 2001; Gillard et al., 2002). In vivo, certain chemokine receptors are expressed constitutively in the developing and adult brain (Hesselgesser and Horuk, 1999; Mennicken et al., 1999), and chemokine expression is induced or upregulated in many neuropathological conditions, including multiple sclerosis (Balashov et al., 1999), stroke (Stanimirovic and Satoh, 2000), and Alzheimer's disease (Horuk et al., 1997; Xia and Hyman, 1999).

Recent studies highlight the roles of specific chemokines and chemokine receptors in cerebellar physiology and development. Gillard et al. (2002) documented the expression of multiple functional chemokine receptors in rat cerebellar granule and Purkinje neurons in vitro, and several chemokine receptors have been identified in vivo in normal mammalian cerebellum, including CXCR2, Duffy antigen receptor for chemokines (DARC) (Horuk et al., 1997), CXCR3 (Goldberg et al., 2001), and CCR3 (Van Der Meer et al., 2001). Overexpression (interleukin-3 [IL$3]$, cytokine-induced neutrophil chemoattractant (KC), 6Ckine) or depletion (IL-6) of certain cytokines or chemokines in mice results in gliosis, abnormal leukocyte infiltration into cerebellar white matter and parenchyma, and behavioral abnormalities (ataxia, rigidity, postural instability, and/or tremor; Campbell et al., 1993; Tani et al., 1996; Sugita et al., 1999; Chen et al., 2002). Moreover, ablation of the $\alpha$-chemokine receptor CXCR4 and its ligand stromal cell derived factor 1 (SDF-1) leads to cerebellar malformation and abnormal granule cell migration (Ma et al., 1998; Zou et al., 1998).

In a recent study of the role of the $\beta$-chemokine macrophage inflammatory protein $1 \alpha$ (MIP-1 $\alpha /$ CCL3) in neonatal brain injury, we found that neurons and astrocytes of the 7-day-old (P7) rat forebrain expressed the MIP-1 $\alpha$ receptor CCR1; in preliminary immunohistochemistry assays of adult brain, no CCR1 was detected (Cowell et al.,

\section{Abbreviations}

$\begin{array}{ll}\text { 5B4-CAM } & \text { 5B4-cellular adhesion molecule } \\ \text { CCR1 } & \beta \text {-chemokine receptor 1 } \\ \text { CNPase } & 2^{\prime} 3^{\prime} \text {-cyclic nucleotide } 3^{\prime} \text {-phosphodiesterase } \\ \text { CTX } & \text { cerebellar cortex } \\ \text { CV } & \text { cresyl violet } \\ \text { DARC } & \text { Duffy antigen/receptor for chemokines } \\ \text { DCX } & \text { doublecortin } \\ \text { DN } & \text { deep nucleus } \\ \text { EGL } & \text { external germinal layer } \\ \text { EGLd } & \text { EGL, differentiating zone } \\ \text { EGLm } & \text { EGL, mitotic zone } \\ \text { GAPDH } & \text { reduced glyceraldehyde-phosphate dehydrogenase } \\ \text { GFAP } & \text { glial fibrillary acidic protein } \\ \text { IGL } & \text { internal granular layer } \\ \text { IP } & \text { immunogenic peptide } \\ \text { KC } & \text { cytokine-induced neutrophil chemoattractant } \\ \text { MIP-1 } \alpha & \text { macrophage inflammatory protein-1 } \alpha \\ \text { ML } & \text { molecular layer } \\ \text { NeuN } & \text { neuron specific nuclear protein } \\ \text { P } & \text { postnatal day } \\ \text { PI3-K } & \text { phosphatidyl inositol-3 kinase } \\ \text { PL } & \text { Purkinje cell layer } \\ \text { Pyk2/RAFTK } & \text { proline-rich tyrosine kinase/related focal adhesion ty- } \\ & \text { rosine kinase } \\ \text { SDF-1 } & \text { stromal cell-derived factor 1 } \\ \text { STAT } & \text { signal transducer } \\ \text { WM } & \text { white matter } \\ & \end{array}$

2002). This finding prompted us to hypothesize that CCR1 expression is developmentally regulated in the rat brain. In light of the evidence cited above suggesting that chemokines and their receptors contribute to cerebellar development, in this study we evaluated the expression of CCR1 in the developing cerebellum. Using a semiquantitative reverse transcriptase polymerase chain reaction assay, we demonstrated that CCR1 mRNA is expressed in rat cerebellum. In addition, we used immunohistochemistry with light and confocal microscopy to document that CCR1 protein is expressed in neuronal and glial cells during rat cerebellar development, specifically during times of neurite extension and cell maturation. Furthermore, immunohistochemistry assays revealed that MIP-1 $\alpha$ is expressed in microglia of cerebellar white matter and in Purkinje cells during the same developmental period.

\section{MATERIALS AND METHODS Antibodies and reagents}

Primary antibodies and reagents included goat anti-rat CCR1 (recognizes carboxyl terminal [intracellular domain]), CCR1 blocking peptide, goat anti-rat CCR5 (all from Santa Cruz Biotechnology, Santa Cruz, CA), mouse anti-NeuN (Chemicon, Temecula, CA), mouse anticalbindin (Sigma, St. Louis, MO), mouse anti-human GFAP (Sigma), rabbit anti-bovine GFAP (Dako, Carpenteria, CA), isolectin $\mathrm{B}_{4}$-peroxidase (Sigma), isolection $\mathrm{B}_{4^{-}}$ fluorescein isothiocyanate (FITC; Sigma), mouse antiendothelin 1 (ED1; Serotec, Oxford, UK), mouse anti-rat 2'3'-cyclic nucleotide 3'-phosphodiesterase (CNPase; Sternberger Monoclonals, Lutherville, MD), rabbit antirat regulated upon activation normal T-cell-expressed and -secreted (RANTES; Peprotech, Rocky Hill, NJ), rabbit anti-rat MIP-1 $\alpha$ (Peprotech), and rabbit anti-rat doublecortin (DCx; generous gift of Dr. Jack Parent, University of Michigan, Ann Arbor, MI). Secondary antibodies and reagents included biotinylated goat anti-rabbit, horse anti-goat, and horse anti-mouse IgG (with minimum cross-reactivity for rat serum proteins; Vector Laboratories, Burlingame, CA), and CY2 donkey anti-mouse IgG (Fab fragments; minimal cross-reactivity for goat, rabbit, and rat serum proteins), CY3 donkey anti-goat IgG (Fab fragments; minimal cross-reactivity for rabbit, mouse, and rat serum proteins), and CY5 donkey anti-rabbit IgG (Fab fragments; minimal cross-reactivity for rat, goat, and mouse serum proteins) from Jackson ImmunoResearch (West Grove, PA). All other reagents were purchased from Sigma unless otherwise noted.

\section{Reverse transcriptase polymerase chain reaction}

Unsexed Sprague-Dawley rats (Charles River, Wilmington, MA) were decapitated on P3, P7, P14, P21, and P60 ( $\mathrm{n}=3$ /group), and the brains were rapidly removed on ice. The cerebellum was separated from the brainstem, homogenized in Tri-Reagent (Molecular Research Center, Cincinnati, $\mathrm{OH}$ ), and stored at $-70^{\circ} \mathrm{C}$. Two cerebella were pooled for the P3 samples; one cerebellum/sample was used for older animals. For a positive control, samples were also obtained from adult spleen, which is enriched in chemokine receptors. RNA was isolated, and RT-PCR was performed as previously described (Galasso et al., 2000), 
with minor modifications. Total RNA ( $1 \mu \mathrm{g})$ was pretreated with DNase ( 15 minutes, $25^{\circ} \mathrm{C}$ ), the reaction was stopped with $2.5 \mathrm{mM}$ EDTA, and DNase was heatinactivated ( 15 minutes, $65^{\circ} \mathrm{C}$ ). Dnase-treated RNA was incubated with $50 \mathrm{U}$ murine leukemia virus (MuLV) RT, 2 $\mathrm{mM}$ random hexamers, and $0.5 \mathrm{mM}$ of each dNTP in a reaction volume of $25 \mu \mathrm{l}$ under the following conditions: 5 minutes, $25^{\circ} \mathrm{C} ; 30$ minutes, $42^{\circ} \mathrm{C} ; 5$ minutes, $99^{\circ} \mathrm{C} ; 1$ minute, $4^{\circ} \mathrm{C}$. The RT product was diluted to a final volume of $100 \mu \mathrm{l}$ in sterile water.

Oligonucleotide primer sets were generated to amplify fragments of rat CCR1 (Boddeke et al., 1999) and glyceraldehyde 3-phosphate dehydrogenase (GAPDH; internal standard). CCR1: 5'-GGA GTT CAC TCA CCA TAC CTG TAG-3'; 5'-GGT CCA GAG GAG GAA GAA-3'; GAPDH: 5'-ACC ACC ATG GAG AAG GCT GG-3'; 5'-CTC AGT GTA GCC CAG GAT GC-3'. GAPDH RNA was assayed concurrently to evaluate the equivalence of RNA content among samples. Preliminary experiments established conditions within the linear range of coamplification for CCR1/GAPDH (15 $\mu \mathrm{l}$ RT product; $0.2 \mu \mathrm{mol} / \mathrm{liter}$ CCR1 primers, $0.04 \mu \mathrm{mol} /$ /iter $\mathrm{GAPDH}$ primers; $94^{\circ} \mathrm{C}$, $60 \mathrm{sec}-$ onds; $60^{\circ} \mathrm{C}, 60$ seconds; $72^{\circ} \mathrm{C}, 90$ seconds; 35 cycles). RTPCR reaction products were visualized in ethidium bromide-stained $1.5 \%$ agarose gels, and results were quantified by fluorometric scanning and the measurement of arbitrary optical density units (counts/mm/band), using the Molecular Analyst Imaging System (Bio-Rad, Hercules, CA).

\section{Immunohistochemistry}

Rats were deeply anesthetized with chloral hydrate (300 $\mathrm{mg} / \mathrm{kg}$ ) on P3, P7, P14, P21, and P60 (n = 3/group) and perfused intracardially with $0.1 \mathrm{M}$ phosphate-buffered saline (PBS, pH 7.4) and 4\% paraformaldehyde. Brains were removed, postfixed overnight in paraformaldehyde at $4^{\circ} \mathrm{C}$, cryoprotected in graded sucrose solutions, embedded in Tissue-Tek OCT (VWR, Batavia, IL), frozen, and stored at $-70^{\circ} \mathrm{C}$ (Ivacko et al., 1996). Serial sections of the cerebellar hemispheres in the translobular (sagittal) plane were mounted on gelatin-coated slides $(15-\mu \mathrm{m}$ sections for light microscopy and $30 \mu \mathrm{m}$ for confocal microscopy). Slides were dried overnight and either used the next day or stored at $-70^{\circ} \mathrm{C}$.

Antibodies were diluted in PBS with 5\% serum (same species as the host of the secondary antibody) and $0.3 \%$ Triton X-100. Sections were washed, blocked in $10 \%$ normal serum, and incubated with the primary antibody overnight at $4^{\circ} \mathrm{C}$. Sections were then washed, incubated with a biotinylated secondary antibody, rinsed with $0.3 \%$ $\mathrm{H}_{2} \mathrm{O}_{2}$ in methanol, and washed before incubation with the avidin-biotin conjugate (Vectastain ABC Elite kit, Vector). Immunoreactivity was visualized with diaminobenzidine (DAB) as the chromogen (Research Genetics, Huntsville, AL). Sections were either counterstained briefly with cresyl violet or directly dehydrated and coverslipped with Permount.

To confirm the specificity of CCR1 immunostaining, CCR1-blocking peptide (10-fold excess w/w) was incubated with the anti-CCR 1 antibody, undiluted, for 1 hour in PBS at room temperature. The peptide-antibody mixture was then diluted (to the same final concentration as for CCR1 immunohistochemistry) and substituted for the primary antibody. This CCR1 antibody has been used successfully to detect receptor upregulation by flow cytometry on as- trocytes (Han et al., 2000) and neutrophils (Johnston et al., 1999). Adult rat spleen sections were used as positive controls for the detection of CCR1 and CCR5. For the negative controls in all other immunohistochemistry experiments, primary antibodies were replaced with an equal concentration of species-matched nonspecific IgG.

Preliminary analysis was performed using light microscopy. Representative images were captured using a SPOT camera attached to a Nikon Microphot-SA with $4 \times, 10 \times$, $20 \times$, and $40 \times$ objectives, and images were directly imported into Adobe Photoshop 5.5 for the adjustment of brightness, contrast, and sharpness. Multiple fields were captured and merged for areas too large to fit into one field (Fig. 2, P14, P21; Fig. 3, adult).

\section{Immunofluorescence}

After incubation with the primary antibodies (overnight at $4^{\circ} \mathrm{C}$ ), sections were washed, incubated with the appropriate secondary antibodies ( 2 hours, room temperature), washed, and coverslipped with aqueous anti-fade media (Molecular Probes, Eugene, OR). Each experiment included controls in which an equal concentration of speciesmatched IgG was substituted for the primary antibody.

Immunofluorescence was visualized in triple-channel mode on a Nikon Diaphot 200 microscope equipped with a Noran confocal laser scanning imaging system and Silicon Graphics Indy workstation. Data were collected from each channel sequentially, and barrier filters minimized channel leakthrough (500/25 bandpass barrier filter in the FITC/CY2 range; 605/55 bandpass barrier filter in the rhodamine/CY3 range). In some cases, immunofluorescence was collected at $0.5-\mu \mathrm{m}$ intervals over $3-10 \mu \mathrm{m}$ thickness (Z-series) to visualize cellular processes. With Adobe Photoshop 5.5, the images from two or three channels were merged, and the brightness and contrast of the images were adjusted.

\section{Qualitative evaluation of CCR1 immunoreactivity}

The distribution and intensity of CCR1 immunoreactivity were systematically evaluated to assess developmental trends. Intensity of CCR1 immunoreactivity in 10 distinguishable cell populations was ranked on a 4-point scale $(+++$, most intense to - , absent). Intensity was assessed with light microscopy (at magnifications of $100 \times$ and $200 \times)$, and specific cell types were identified by their morphology and location (with reference to the confocal microscopy results). Conclusions were based on evaluation of immunoreactivity in lobes VI-IX, in two sections from each age group, assayed concurrently. Trends were confirmed in three separate experiments (one animal/group/ experiment).

\section{RESULTS \\ Developmental change in CCR1 RNA expression}

Using RT-PCR assays, CCR1 mRNA was detected in P3, P7, P14, and P21 and in adult (P60) cerebellar tissue (Fig. 1). Densitometric analysis indicated that there was a modest increase in expression between P3 and adult $(50 \%$ increase; $\mathrm{n}=3$ /group; $P=0.05$, Kruskal-Wallis test). Expression levels in P7, P14, and P21 cerebellum were intermediate and did not differ from one another. 


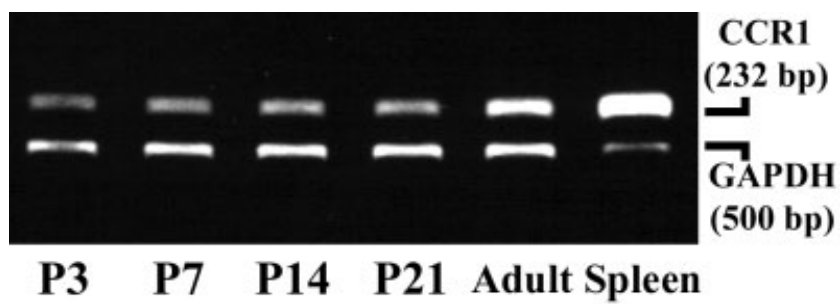

Fig. 1. Semiquantitative RT-PCR assay of CCR1 mRNA. RNA was isolated from rat cerebellum (P3, P7, P14, P21, adult) and adult spleen (positive control), reverse transcribed, and amplified with CCR1- and GAPDH-specific primers (see Materials and Methods). CCR1 mRNA content (normalized to GAPDH mRNA) was 50\% higher in the adult cerebellum than in P3 cerebellum (see Results). For abbreviations, see list.

\section{Developmental changes in CCR1 immunoreactivity}

To determine the neuroanatomical and cell-specific distribution of CCR1 protein expression, cerebellar tissue sections were analyzed by immunohistochemistry. Figure 2 illustrates the developmental changes in distribution and intensity of cerebellar CCR1 immunoreactivity from P3 to adulthood. CCR1 immunoreactivity is abolished in serial sections for which the primary antibody was incubated with the immunogenic blocking peptide (IP; Fig. 2). Numerous cells throughout the cerebellar cortex are labeled lightly on P3; immunostaining is more intense from P7 to P21 and declines in adulthood. The intensity and distribution of CCR1 immunoreactivity (detailed below) is similar in all lobes.

CCR1-immunoreactive cells are located in the Purkinje cell layer (PL), internal granular layer (IGL), deep nucleus (DN), and molecular layer (ML) at different ages (all neuroanatomical nomenclature from Altman and Bayer, 1997). CCR1 immunoreactivity is also evident on cells within P3 (Fig. 2A $\mathrm{A}_{2}$ ), P7 and P14 white matter (WM; see Fig. 5). Large cells in the forming PL are CCR1-positive at P3 (Fig. 2A $)$, P7 (Fig. 2B ${ }_{2}$ ), and P14 (Fig. 2C ${ }_{2}$ ). Smaller immunoreactive cells are observed in the IGL from P7 to adulthood (Fig. $2 \mathrm{~B}_{2}, \mathrm{C}_{2}, \mathrm{D}_{2}, \mathrm{E}_{2}$ ). In the $\mathrm{DN}$, there are large CCR1-immunoreactive cells on P3, P7, and P14 (Fig. $2 \mathrm{~A}_{3}, \mathrm{~B}_{3}, \mathrm{C}_{3}$, respectively); however, very little CCR1 immunoreactivity is detectable in P21 and adult DN (data not shown). It is especially evident in this cell type that CCR1 immunoreactivity is cytoplasmic $\left(\right.$ Fig. $\left.2 \mathrm{~A}_{3}, \mathrm{C}_{3}\right)$ and nuclear (Fig. $2 \mathrm{~B}_{3}$, arrowhead). Within the molecular layer (ML), few CCR1-immunoreactive cells are observed at P7 (Fig. $2 \mathrm{~B}_{2}$ ), but at $\mathrm{P} 14$, cells intensely immunoreactive for CCR1 are concentrated at the $\mathrm{ML} / \mathrm{PL}$ border (Fig. $2 \mathrm{C}_{2}$ ). Immunoreactive cells are distributed throughout the ML at P21 (Figs. $2 \mathrm{D}_{2}, \mathrm{D}_{3}$ ) but are absent from the adult ML (Fig. $\left.2 \mathrm{E}_{3}\right)$.

Figure 3 highlights the changes in CCR1 distribution between P7 and P21 in cerebellar cortex. During this time, the ML expands, the external germinal layer (EGL) thins, and the Purkinje cells form a monolayer. These structural changes are evident in cresyl violet-stained sections (Fig. 3, left column). CCR1-immunostained serial sections are represented in the center column (Figs $3 \mathrm{~A}_{2}, \mathrm{~B}_{2}, \mathrm{C}_{2}$, respectively) and the negative controls in the right column (Fig. $3 \mathrm{~A}_{3}, \mathrm{~B}_{3}, \mathrm{C}_{3}$ ).
At P7 (Fig. $3 \mathrm{~A}_{2}$ ), many cells are immunoreactive for CCR1; large cells in the PL are the most prominent (Fig. $3 \mathrm{~A}_{2}$, arrowheads). Numerous cells throughout the IGL and adjacent white matter are immunoreactive, including several immunoreactive Golgi cells (Fig. $3 \mathrm{~A}_{2}$, arrows). Few cells in the ML express CCR1 (Fig. $3 \mathrm{~A}_{2}$, open arrow).

On P14, only a few large cells are immunoreactive in the $\mathrm{PL}$ (Fig. $3 \mathrm{~B}_{2}$, arrowheads); however, many small, intensely immunoreactive cell bodies are concentrated within and just superficial to the PL (Fig. $3 \mathrm{~B}_{2}$, solid arrows). Small immunoreactive cells are also seen in the lower molecular layer (Fig. $3 \mathrm{~B}_{2}$, open arrows). Note that a small fraction of descending granule cells is immunoreactive (Fig. $3 \mathrm{~B}_{2}$, open arrowhead; compare with the frequency of similarly shaped cells in Fig. $3 \mathrm{~B}_{1}$ ).

On P21 in the PL, only small cell bodies are immunoreactive, and immunostaining within the IGL is less intense (Fig. $3 \mathrm{C}_{2}$ ). In contrast to $\mathrm{P} 7$ and $\mathrm{P} 14$ cerebellum, numerous cell bodies throughout the ML express CCR1. Small cell bodies in the upper ML display intense immunoreactivity uniformly throughout the cell body (Fig. $3 \mathrm{C}_{2}$, arrowheads), and cells in the lower ML exhibit immunoreactivity limited to the cytoplasm and cell surface (Fig. $3 \mathrm{C}_{2}$, arrows).

Cerebellar sections from each age group were analyzed concurrently for CCR5 immunoreactivity. No CCR5 immunoreactivity was detected until P21; immunoreactivity was limited to endothelium and pia in P21 and adult cerebellum (not shown).

\section{Identification of CCR1-expressing cell types}

To determine the identity of CCR1-expressing cells and to reveal maturational changes in the morphology and distribution of neuronal and non-neuronal cells, we performed immunohistochemistry on serial cerebellar sections with the CCR1 antibody and cell-specific markers. We used antibodies or lectins specific for neurons (antiNeuN), Purkinje cells (anti-calbindin), Bergmann/radial glia and astrocytes (anti-GFAP), and resting microglia and capillary endothelium (isolectin). In Figure 4, the distributions of these antigens are compared with cresyl violet staining (Fig. 4A) and CCR1 immunohistochemistry (Fig. 4B).

The neuron-specific protein NeuN (Fig. 4C) is expressed in many cells in the EGL and IGL and in scattered cells throughout the $\mathrm{ML}$, in a pattern similar to that of granule cells. Although little CCR1 is expressed in the EGL (Fig. 4B), CCR1-positive cells in the IGL at P7, P14, and P21 (Fig. 4B) have the same size and shape as NeuN-positive cells (Fig. 4C), suggesting that CCR1 is expressed in granule cells of the IGL. In contrast, at P21 NeuN and CCR1 immunoreactivity differs substantially in the ML; comparison of cresyl violet and $\mathrm{NeuN}$ staining at P21 (Fig. $4 \mathrm{~A}_{3}, \mathrm{C}_{3}$ ) indicates that many of the cresyl violet-stained cells with the morphology of ML interneurons (large round cells in the lower ML and smaller cells in the upper ML) express little detectable NeuN. These presumptive ML interneurons, however, are similar in morphology to CCR1-positive cells in the ML (Fig. 4B S $_{3}$.

In the cerebellum, the calcium-binding protein calbindin is concentrated in Purkinje cells. Calbindin immunostaining reveals that Purkinje cells form a monolayer by P7 (Fig. 4D ), and their dendrites extend into the molecular cell layer at P14 (Fig. $4 \mathrm{D}_{2}$ ), forming a dense network in the ML by P21 (Fig. $4 \mathrm{D}_{3}$ ). When CCR1 and calbindin 

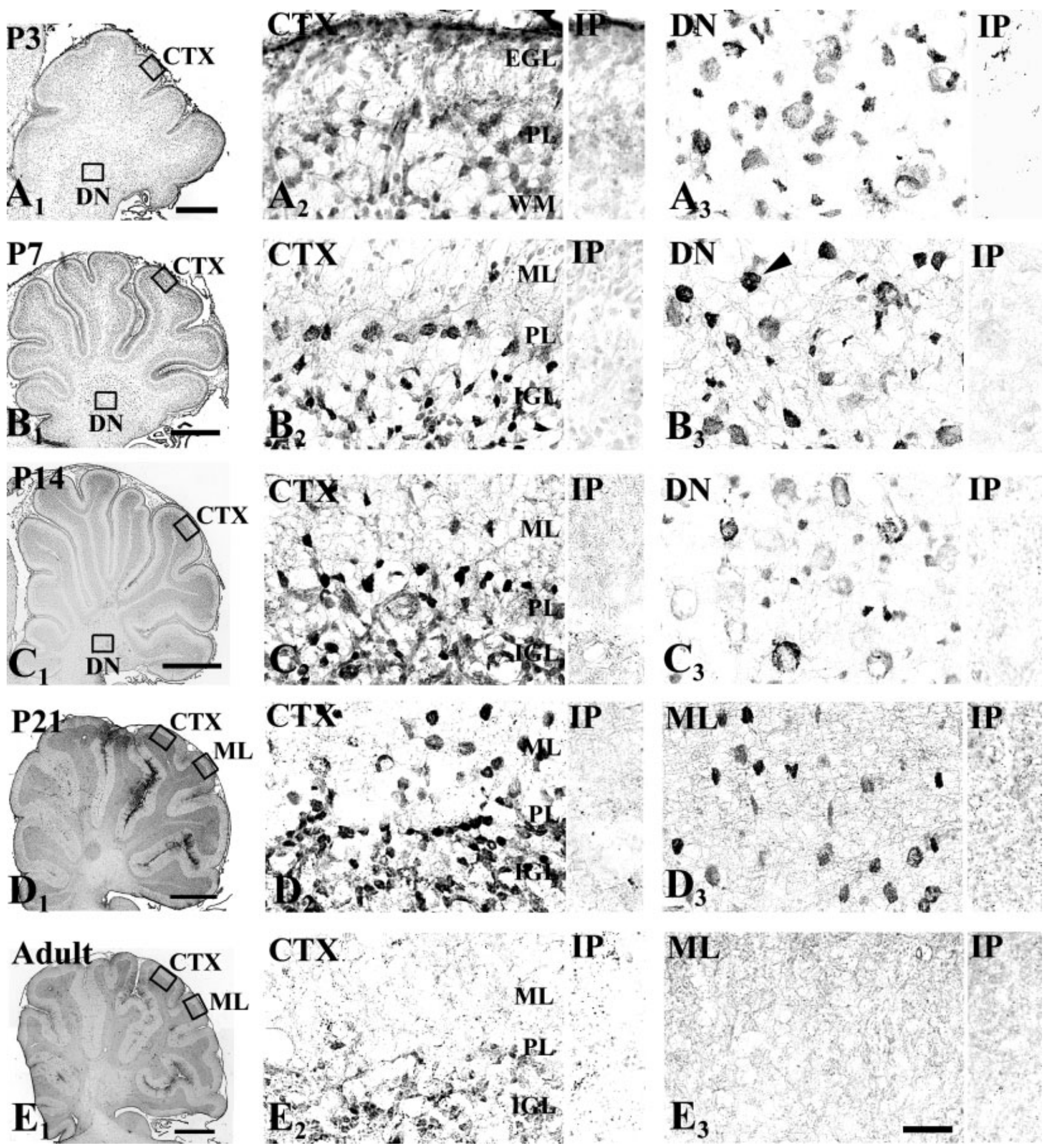

Fig. 2. CCR1 immunoreactivity in the developing and mature rat cerebellum. Low-power image montages of CCR1-immunostained cerebellar tissue, sectioned in the translobular (sagittal) plane, are presented in the left column. Boxed areas identify specific regions, shown at higher power in the middle and right columns. Serial sections were processed concurrently using primary antibody preincubated with an immunogenic peptide (IP; see Materials and Methods) and are displayed to the right of the corresponding CCR1 immunohistochemistry section; minimal nonspecific staining was detected in all sections. A: On P3, scattered cells are immunoreactive for CCR1 within the PL and WM $\left(\mathrm{A}_{2}\right)$, and large ovoid cells are immunoreactive in the DN $\left(\mathrm{A}_{3}\right)$. B: Similarly, on P7, large cells in the PL $\left(B_{2}\right)$, smaller cells in the forming IGL $\left(\mathrm{B}_{2}\right)$, and large cells in the DN $\left(\mathrm{B}_{3}\right)$ stain darkly for CCR1. Some cells in the DN display nuclear CCR1 immunoreactivity $\left(\mathrm{B}_{3}\right.$ arrowhead). C: On P14, CCR1 immunoreactivity intensifies in the IGL and in cells along the PL/ML border $\left(\mathrm{C}_{2}\right)$. Immunopositive cells are also seen in the ML $\left(\mathrm{C}_{2}\right)$. Large cells in the DN display cytoplasmic and cell surface immunoreactivity $\left(\mathbf{C}_{3}\right)$. D: On P21, there are immunopositive cells in the IGL $\left(\mathrm{D}_{2}\right)$ as well as throughout the lower and upper $\mathrm{ML}\left(\mathrm{D}_{2}\right.$ and $\mathrm{D}_{3}$, respectively). E: In the adult cerebellum, faintly immunoreactive cells are located in the IGL $\left(\mathrm{E}_{2}\right)$, whereas there are no immunopositive cells in the ML $\left(\mathrm{E}_{3}\right)$. For abbreviations, see list. Scale bars $=250 \mu \mathrm{m}$ in $\mathrm{A}_{1} ; 500 \mu \mathrm{m}$ in $\mathrm{B}_{1} ; \mathrm{C}_{1}-\mathrm{E}_{1}, 1 \mathrm{~mm}$ in $\mathrm{C}_{1}-\mathrm{E}_{1} ; 25 \mu \mathrm{m}$ in all other panels. 


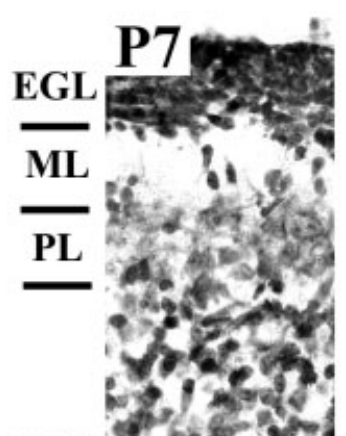

IGL $y^{2}$ of

- Mgentio. So, 0,0

$\overline{\mathrm{WM}}$

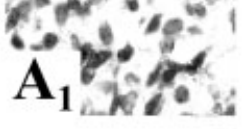

P14

EGL

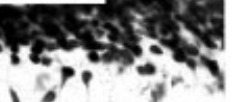

ML $:\left\{\begin{array}{l}1 \\ 1\end{array}\right.$

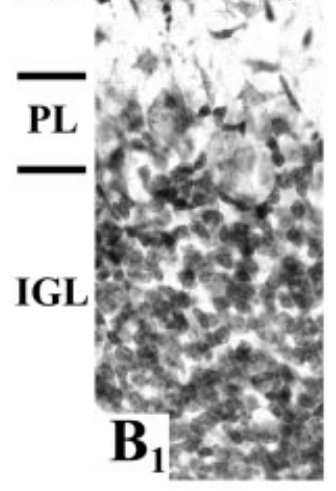

P21 . . .

- $a^{1}$

ML $: 1$<smiles>CCCCC(C)C</smiles>

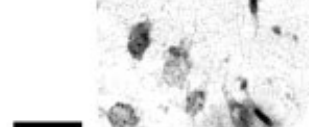

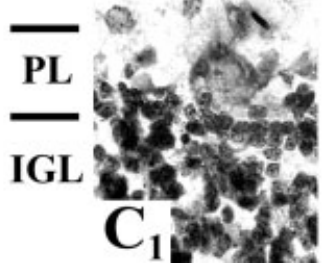

$8 \%$

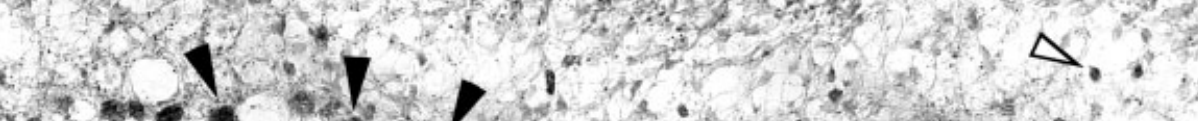

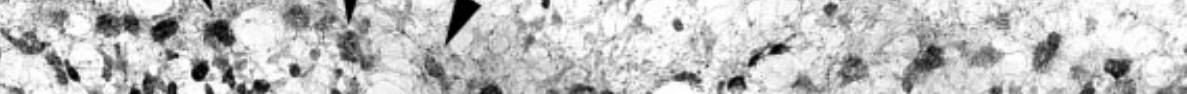

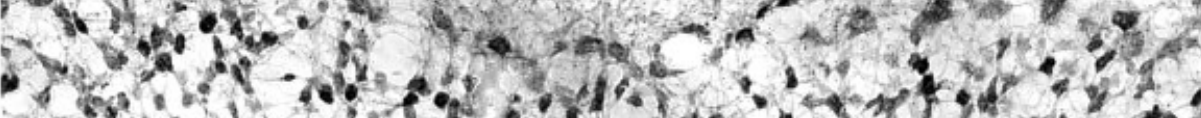

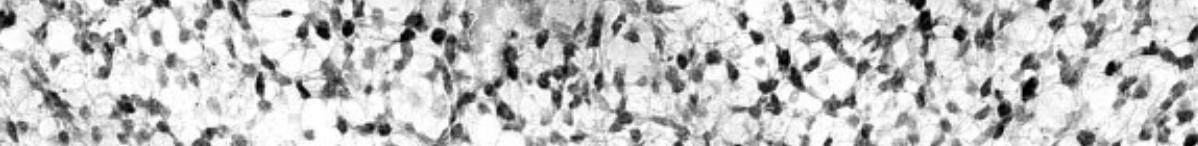

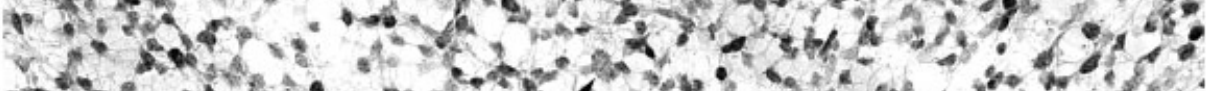

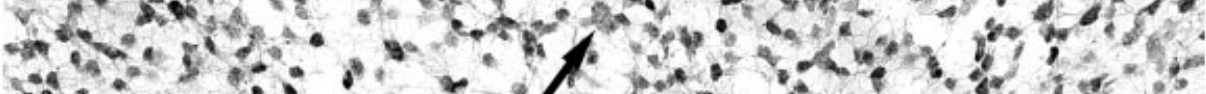

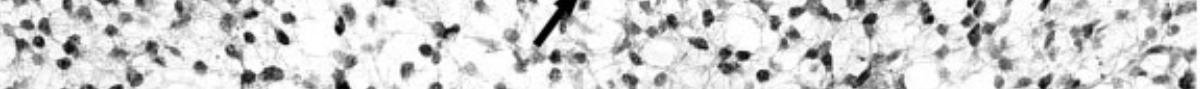

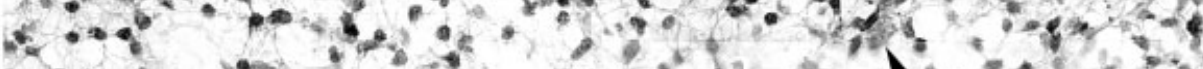

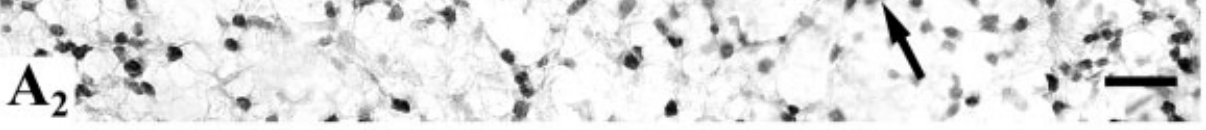

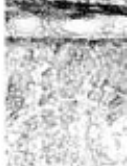

$80 .+2$ S.

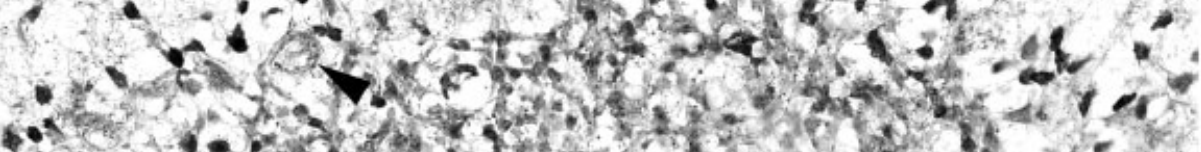

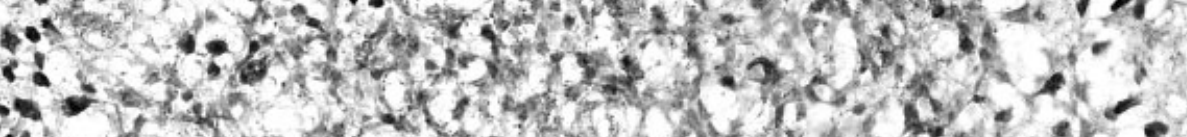

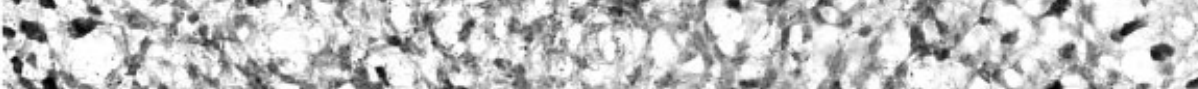

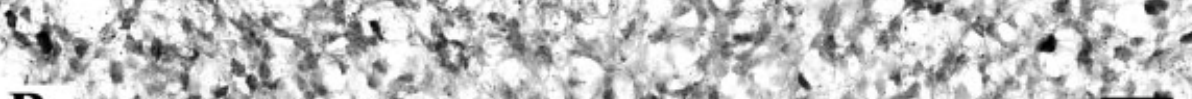

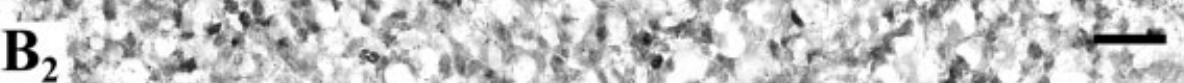

$\mathbf{B}_{3}$
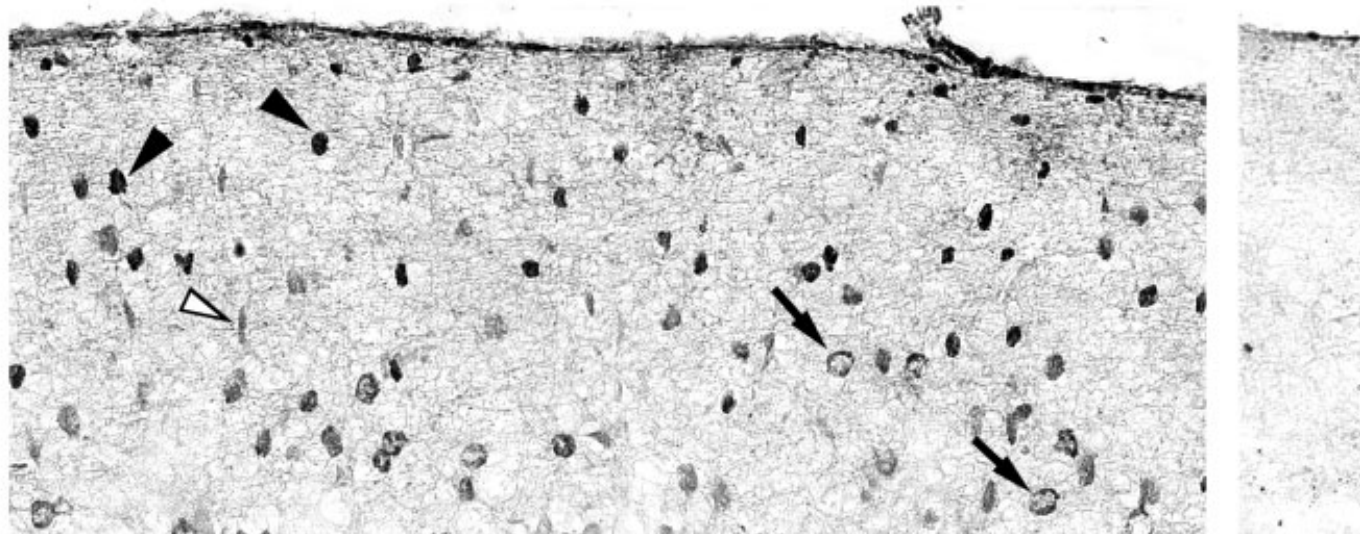
immunoreactivity distributions are compared at P7 (Fig. $4 \mathrm{~B}_{1}, \mathrm{D}_{1}$, respectively), it is not possible to determine whether Purkinje cells express CCR1, but calbindinpositive Purkinje cells are clearly CCR1-negative at P21 (Fig. $4 \mathrm{~B}_{3}$, arrows, and $\mathrm{D}_{3}$ ).

From P7 to P21, GFAP-positive Bergmann glia mature and form distinct radial fibers (Fig. 4E). On P14, GFAP is concentrated in glial cell bodies and throughout the radial processes (Fig. $4 \mathrm{E}_{2}$, arrowheads). The GFAP staining of Bergmann glial cell bodies resembles the CCR1 immunostaining in the PL and lower ML at

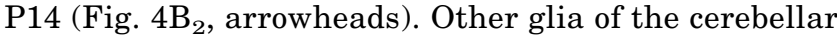
cortex include the astrocytes and the resting microglia of the IGL. Relatively few astrocytes (Fig. $4 \mathrm{E}_{2}$ ) and resting microglia (distinguishable from capillaries by their elaborate processes; Fig. $4 \mathrm{~F}_{1}-\mathrm{F}_{3}$, arrowheads) are present in the IGL from P7 to P21, indicating that most CCR1-immunoreactive cells in the IGL are not astrocytes or microglia.

Figure 5 illustrates the developmental changes in the distribution of CCR1 immunostaining and cell types in the cerebellar white matter from P7 to P21. We observed many CCR1-positive cells in the white matter on P7 and $\mathrm{P} 14$, in areas devoid of neurons (Fig. 5, compare $\mathrm{B}_{1}$ and $\mathrm{C}_{1}, \mathrm{~B}_{2}$ and $\mathrm{C}_{2}$ ). We used immunohistochemistry to identify astrocytes (GFAP), activated microglia (ED1), and oligodendroglial processes and cell bodies (CNPase) (Fig. 5DF). From P7 to P21, numerous astrocytes are concentrated in the white matter (Fig. 5D); the density of GFAPpositive cell bodies and processes is the highest at P14 (Fig. 5D $\mathrm{D}_{2}$ ). On $\mathrm{P} 7$ and $\mathrm{P} 14$, activated microglia reside in the white matter (Fig. $5 \mathrm{E}_{1}, \mathrm{E}_{2}$ ), but at P21, no ED1positive microglia are present. CNPase immunostaining is absent in $\mathrm{P} 7$ white matter (Fig. $5 \mathrm{~F}_{1}$ ) but is readily dis-

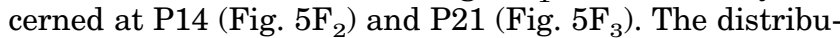
tion of CCR1 immunostaining is similar to the distribution of GFAP and ED1 staining, but the precise identification of CCR1-expressing cell types required the

Fig. 3. Distribution of cerebellar CCR1 immunoreactivity from P7 to P21. Each row includes corresponding image montages of cresyl violet staining (left column), CCR1 immunohistochemistry (middle column), and the negative control (right column; assay performed using CCR1 antibody, preincubated with a blocking peptide). Results are compared on P7 $\left(\mathrm{A}_{1}-\mathrm{A}_{3}\right), \mathrm{P} 14\left(\mathrm{~B}_{1}-\mathrm{B}_{3}\right)$, and P21 $\left(\mathrm{C}_{1}-\mathrm{C}_{3}\right)$. The layers of the cerebellar hemisphere are labeled accordingly. A: On P7, CCR1 immunoreactivity $\left(\mathrm{A}_{2}\right)$ is concentrated on large cells in the PL (arrowheads) and on numerous cells with the morphology of granule cells and Golgi cells (filled arrows) throughout the forming IGL. In the ML cells immunoreactive for CCR1 are occasionally identified (open arrowhead). Little immunoreactivity is present in the EGL. B: On P14, few large cells in the PL are immunoreactive for CCR1 $\left(\mathrm{B}_{2}\right.$, filled arrowheads); however, many smaller cell bodies express CCR1 within and just superficial to the PL (arrows). CCR1-positive cells are more widely distributed throughout the ML (open arrows) and include occasional spindle-shaped descending granule cells (open arrowhead). In the IGL, there are many immunoreactive granule cells. Little specific staining is present in the EGL. C: On P21, no large CCR1positive cell bodies are found in the PL, whereas granule cells in the IGL remain immunoreactive. In the ML, there are many CCR1immunoreactive cells, including those with darkly stained cell somata in the upper ML (filled arrowheads), less intensely immunostained cells with signal often limited to the cell surface in the lower ML (arrows), and occasional descending granule cells (open arrowhead). Nonspecific staining is limited to the pia in all negative controls. For abbreviations, see list. Scale bars $=25 \mu \mathrm{m}$ in A-C. incorporation of double- and triple-labeling immunofluorescence experiments (see below).

\section{MIP-1 $\alpha$ expression in postnatal and adult cerebellum}

The widespread distribution of CCR1 immunoreactivity in the developing cerebellum prompted us to evaluate the expression of the CCR1 ligands MIP-1 $\alpha$ and RANTES (/CCL5). No RANTES immunoreactivity was detectable at any developmental age (not shown), but we observed MIP$1 \alpha$-immunoreactive cells in the P7-adult cerebellum (Fig. 6). MIP-1 $\alpha$-immunoreactive cells included Purkinje cells (Fig. 6B-E) and cells in P7 and P14 white matter (Fig. 6F). Figure $6 \mathrm{~F}$ illustrates the distinctive juxtanuclear MIP-1 $\alpha$ immunostaining pattern (Lore et al., 1998; Cowell et al., 2002) observed in large cell bodies within white matter tracts in $\mathrm{P} 7$ and $\mathrm{P} 14$ animals (Fig. $6 \mathrm{~F}_{1}$ ). In serial sections, these cells stain darkly for the monocyte/microglial marker ED1 (Fig. $6 \mathrm{~F}_{2}$ ), suggesting that activated microglia are a source for MIP-1 $\alpha$; in the developing cerebellum.

The somata and dendrites of Purkinje cells are also immunopositive for MIP-1 $\alpha$ (Fig. 6C-E and 6G, arrowheads). Little nonspecific staining is observed when nonspecific rabbit IgG is substituted for the MIP- $1 \alpha$ antibody (Fig. 6G $\mathrm{G}_{2}$ ). Calbindin immunohistochemistry demonstrates that the MIP- $1 \alpha$-positive cells have the morphology of Purkinje cells (Fig. $6 \mathrm{G}_{3}$ ).

\section{Triple-immunofluorescent labeling}

The above data suggest that CCR 1 and MIP-1 $\alpha$ are expressed in both neurons and non-neuronal cells in the developing cerebellum. To confirm the identity of the CCR1- and MIP-1 $\alpha$-expressing cells, we performed doubleand triple-immunofluorescence assays and analyzed the specimens with confocal microscopy. In some cases, fluorescence was collected from multiple planes (Z-series) to reveal the morphology of cells and their processes (as indicated below).

Figure 7 presents confocal images that demonstrate the distribution of CCR1 immunoreactivity in each cerebellar cell type. In the deep nucleus, CCR1 immunoreactivity is most intense at P7 (see Fig. $2 \mathrm{~B}_{3}$ ); Figure $7 \mathrm{~A}$ shows that CCR1 immunoreactivity colocalizes with NeuN, indicating that CCR 1 is expressed by deep nucleus neurons. In the IGL, at the peak of CCR1 expression (P14; see Fig. 2C), most CCR1-immunoreactive cells are neurons (NeuN-positive; Fig. 7B). A minority of CCR1-positive cells are astrocytes with GFAP-positive cell bodies and processes (Fig. 7C; Z-series). Also in the IGL at P14, a few CCR1positive cell bodies display the isolectin-positive elaborate processes of resting microglia (Fig. 7D; Z-series). Some resting microglia express CCR1 (Fig. 7D, solid arrowheads), whereas others do not (Fig. 7D, open arrowheads).

Numerous CCR1-positive NeuN-negative cells are concentrated in cerebellar white matter at P7 (Fig. 7E). Most of these cells have GFAP-positive processes (Fig. 7F, arrowheads). Activated microglia (ED1-labeled) rarely express CCR1, and CCR1 immunoreactivity never colocalizes with CNPase (not shown). Of interest, in regions of white matter where CCR1-positive astrocytes are found, MIP-1 $\alpha$-expressing activated microglia are observed (Fig. $7 \mathrm{G})$. MIP-1 $\alpha$ immunoreactivity is concentrated adjacent to the nucleus [stained with propidium iodide (PI)], in a pattern similar to the staining of Golgi apparatus (Lore et al., 1998). 

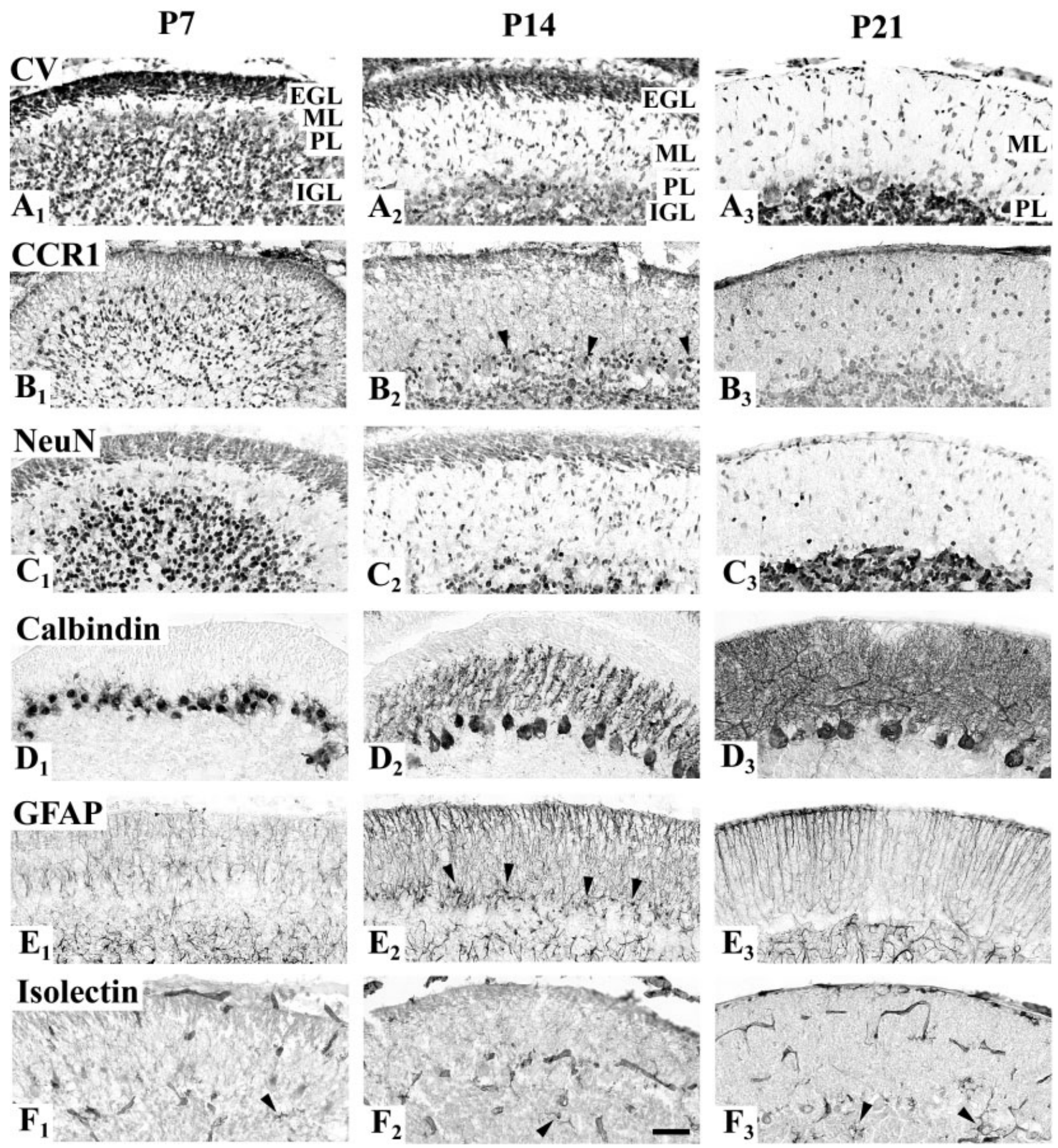

Fig. 4. Changes in CCR1 immunostaining and neural and glial markers in cerebellar cortex from P7 to P21. Each column includes results of assays on serial cerebellar sections, obtained at P7 (left column), P14 (middle column), and P21 (right column). A: Cresyl violet (CV) staining reveals the thinning of the EGL, expansion of the ML, and organization of the PL and IGL by P21. B: CCR1 immunohistochemistry demonstrates major changes in the distribution of CCR1 expression between $\mathrm{P} 7$ and $\mathrm{P} 21$; in $\mathrm{B}_{2}$, arrowheads point to small immunoreactive cells in the PL. C: The distribution of NeuNimmunoreactive neurons also changes substantially over this period and, in general, corresponds to the redistribution of cresyl violetstained cells. However, at P21, there are fewer NeuN-positive cells in

the ML $\left(\mathrm{C}_{3}\right)$ than cresyl-violet-stained $\left(\mathrm{A}_{3}\right)$ or CCR1-immunoreactive cells $\left(B_{3}\right)$. D: Calbindin immunohistochemistry illustrates marked developmental changes in Purkinje cells from P7 to P21; these cells extend their dendrites to form a dense network in the ML by P21 $\left(D_{3}\right)$. E: During the same time interval, there are prominent maturational changes in Bergmann glia and a marked increase in GFAP immunostaining of glial processes in the ML; of note, at P14, in the PL, GFAP-positive cell bodies (arrows in $\mathrm{E}_{2}$ ) are concentrated in the same regions as CCR1-positive cells (arrows in $\mathrm{B}_{2}$ ). F: Isolectin $\mathrm{B}_{4}$ histochemistry (to identify microglia and capillaries) indicates that there are few microglia (arrowheads) in the cerebellar lobules between P7 and P21. For abbreviations, see list. Scale bar $=50 \mu \mathrm{m}$ in A-F 
P7

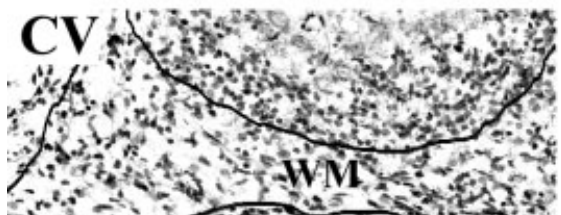

$\mathbf{A}_{1}$ Pind

CCR1 34

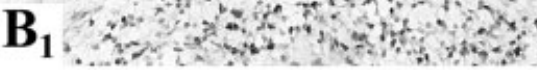
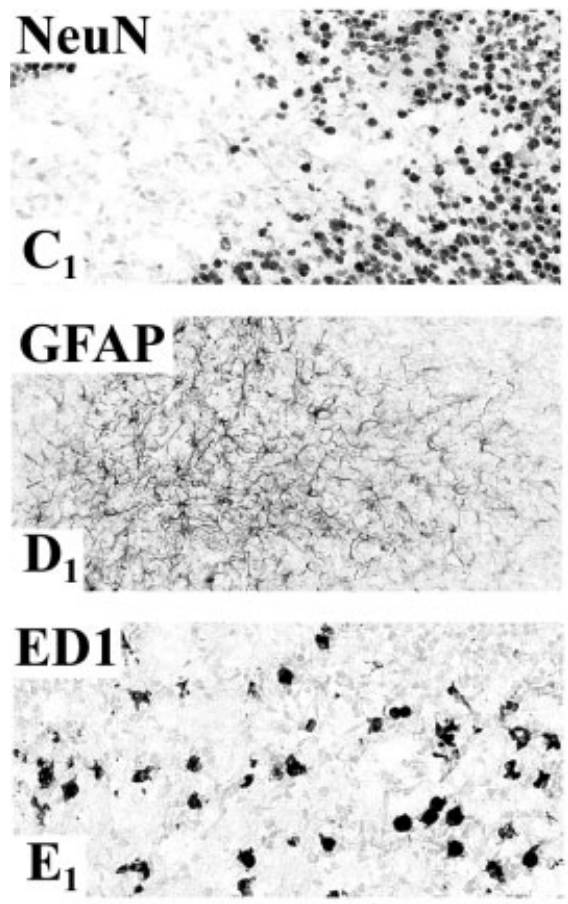

\section{CNPase}

$\mathbf{F}_{1}$
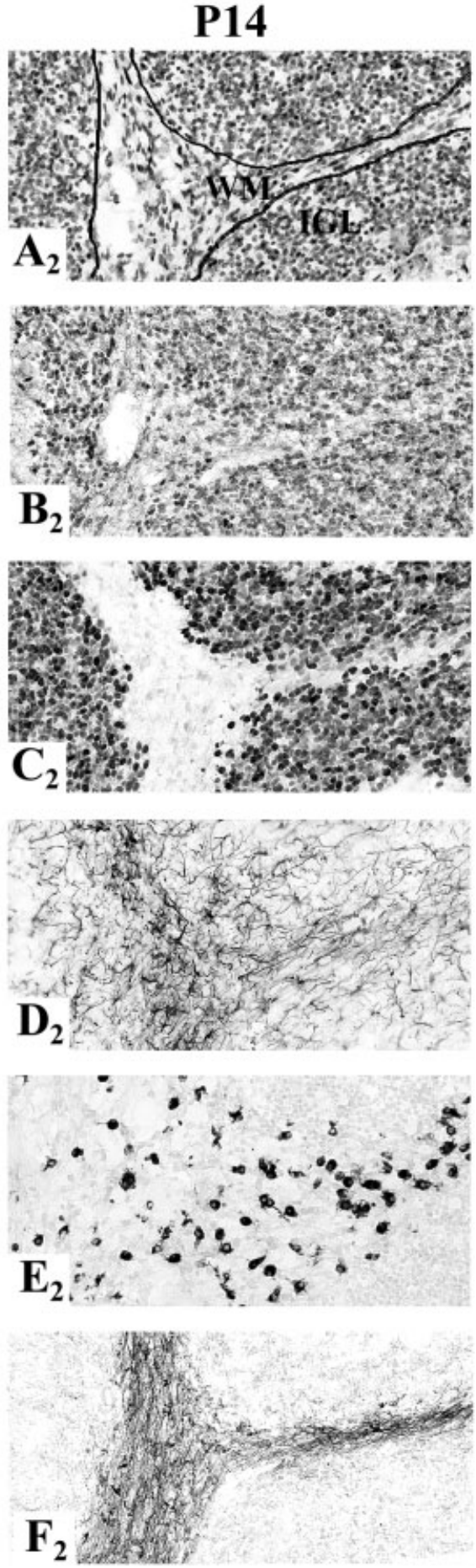

$\mathbf{E}_{3}$
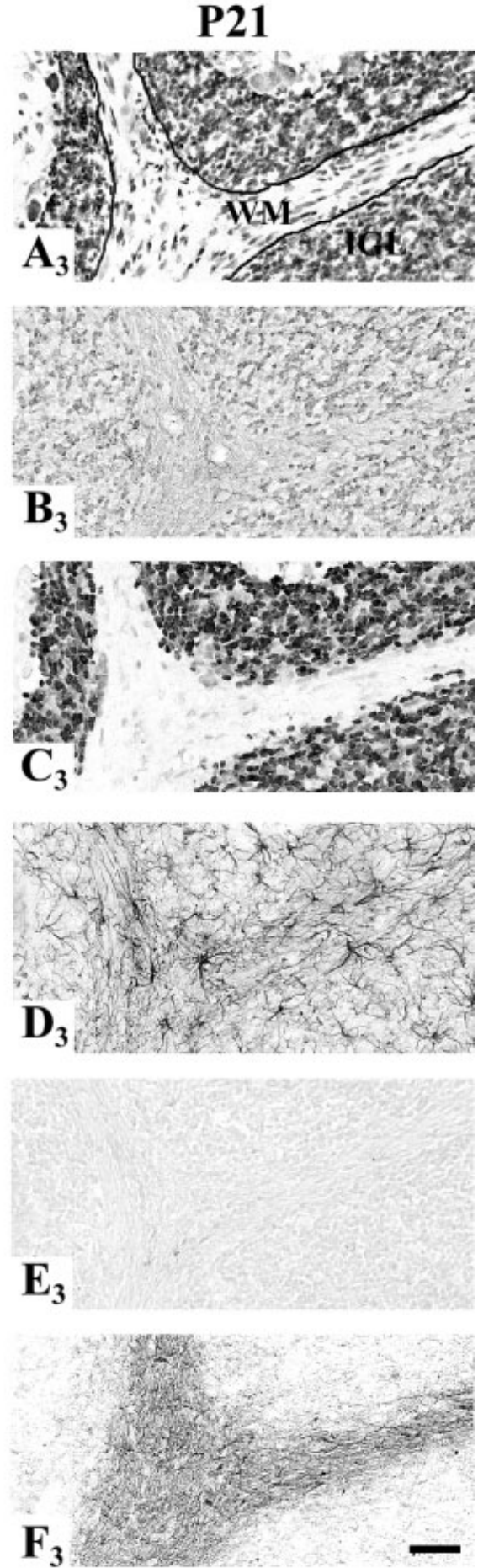

Fig. 5. Changes in CCR1 immunostaining and cellular distribution in cerebellar white matter from P7-21. Each column includes results of assays on serial cerebellar sections, obtained at P7 (left column), P14 (middle column) and P21 (right column). Black lines drawn in $\mathrm{A}_{1}-\mathrm{A}_{3}$ define the border between the WM and the IGL. A: Cresyl violet (CV) staining reveals the high density of cell bodies in the WM at P7 $\left(\mathrm{A}_{1}\right)$ and $\mathrm{P} 14\left(\mathrm{~A}_{2}\right)$ and the reduction in cell density at P21 $\left(\mathrm{A}_{3}\right)$. B: CCR1 immunohistochemistry identifies numerous CCR1positive cells in the WM at P7 $\left(\mathrm{B}_{1}\right)$ and P14 $\left(\mathrm{B}_{2}\right)$ and the absence of staining in WM on P21 $\left(\mathrm{B}_{3}\right)$. C: There is little NeuN immunoreactivity in the WM at all time points. D: Many GFAP-positive astrocytes are present in WM at all three ages; cell density appears highest at P14 $\left(\mathrm{D}_{2}\right)$. E: In contrast, ED1-immunostained physiologically activated microglia are concentrated in WM at P7 $\left(\mathrm{E}_{1}\right)$ and $\mathrm{P} 14\left(\mathrm{E}_{2}\right)$ but are absent by P21 $\left(\mathrm{E}_{3}\right)$. F: Oligodendroglial cell bodies and processes, detectable with CNPase immunohistochemistry, are evident on P14 $\left(\mathrm{F}_{2}\right)$ and P21 $\left(\mathrm{F}_{3}\right)$. For abbreviations, see list. Scale bar $=50 \mu \mathrm{m}$ in $\mathrm{A}-\mathrm{F}$. 

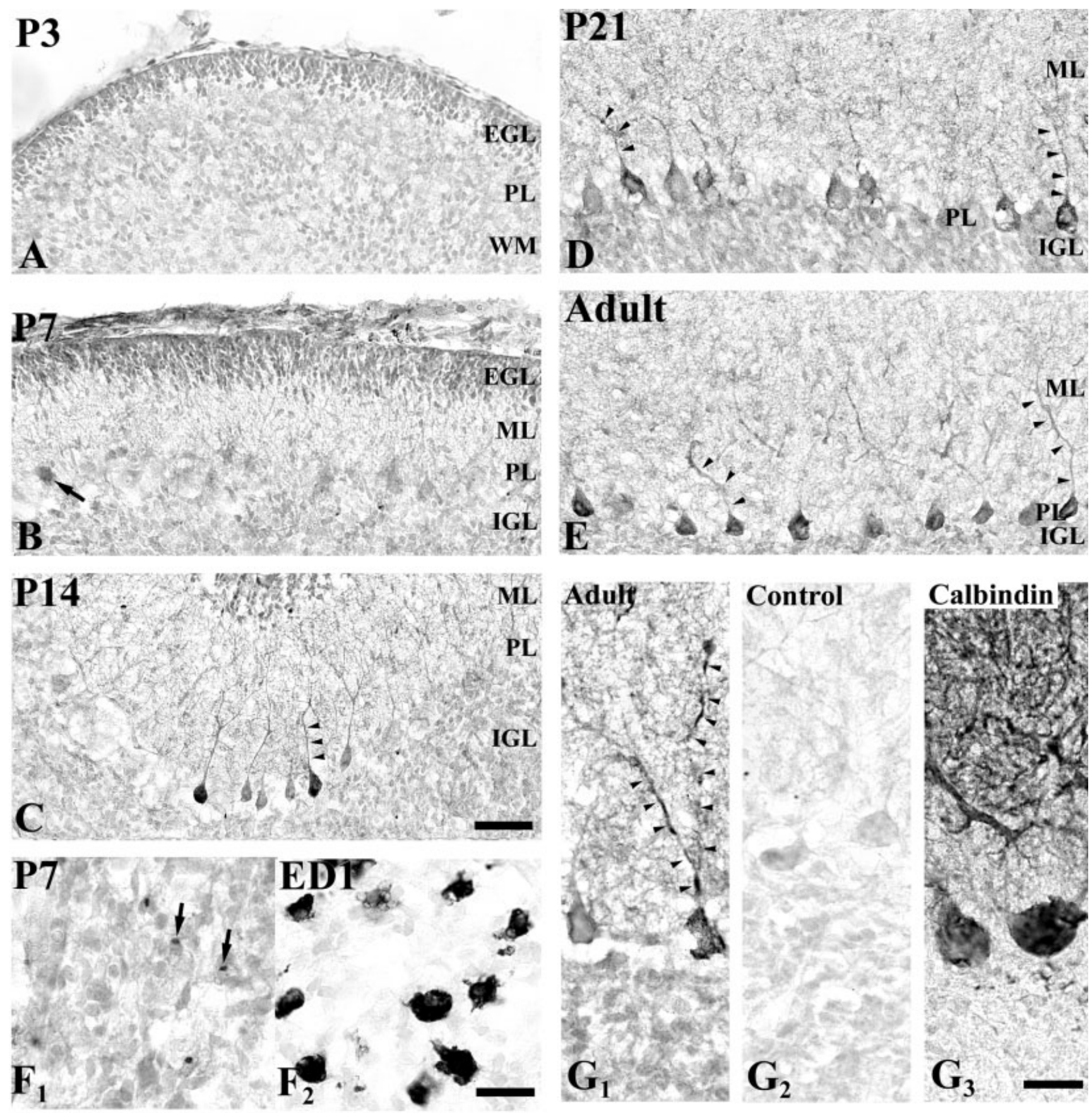

Fig. 6. Macrophage inflammatory protein-1 $\alpha$ immunoreactivity in the postnatal rat cerebellum. In the cerebellar cortex, MIP-1 $\alpha$ immunoreactivity is absent at P3 (A) and infrequently observed on cells in the PL at P7 (arrow, B). Immunostaining is more intense at P14 (C), with some Purkinje cells, but not all, immunoreactive for MIP-1 $\alpha$. In P21 (D) and adult (E) cerebellum, Purkinje cells are more uniformly stained. MIP-1 $\alpha$ immunoreactivity is detectable in the cell soma as well as in apical dendrites (arrowheads, C-E). In the white matter on P7, "juxtanuclear" MIP-1 $\alpha$ (arrows in $\mathbf{F}_{1}$ see text) is identified, coinciding with the distribution of physiologically activated microglia

Figure 7H-J demonstrates the marked developmental change in Purkinje cell CCR1 expression. In the PL at P7, all calbindin-positive Purkinje cells express CCR1 (Fig. 7H). At

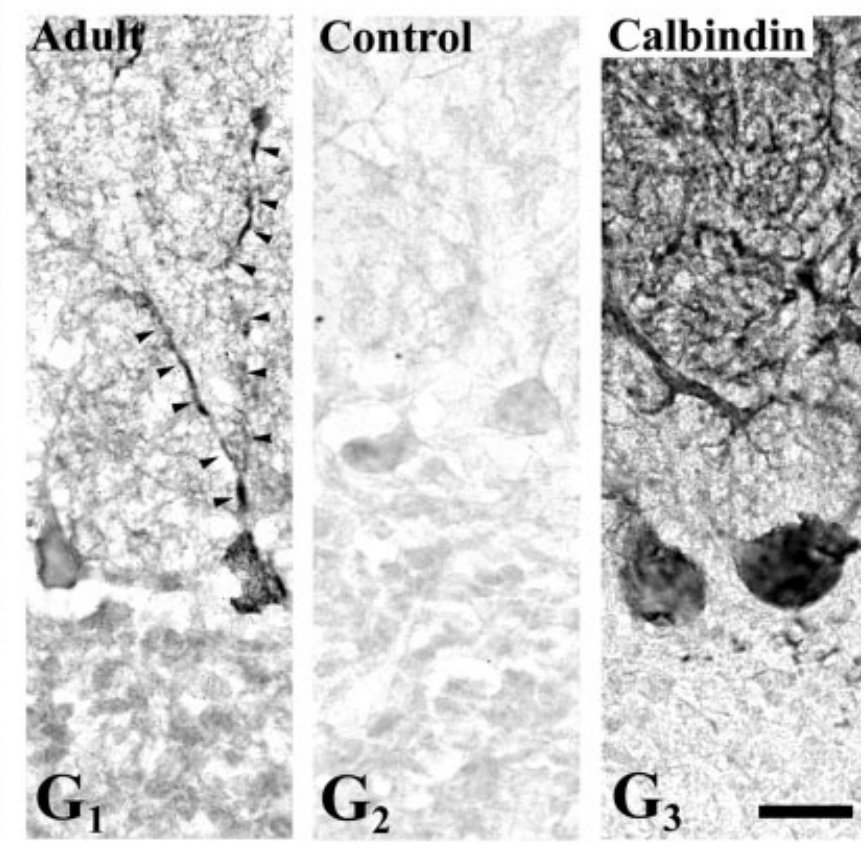

(serial section, immunohistochemistry for monocytic marker ED1, $\mathrm{F}_{2}$ ). In adult cerebellum, the cytoplasmic and dendritic distribution of MIP- $1 \alpha$ in Purkinje cells is evident (arrowheads, $G_{1}$ ). The negative control section, in which species-matched IgG was substituted for the MIP- $1 \alpha$ antibody, confirms the specificity of MIP- $1 \alpha$ immunostaining $\left(\mathrm{G}_{2}\right)$, and calbindin immunohistochemistry confirms that MIP- $1 \alpha-$ immunoreactive cells have the morphology of calbindinimmunoreactive Purkinje cells $\left(G_{3}\right)$. For abbreviations, see list. Scale bars $=50 \mu \mathrm{m}$ in A-E; $25 \mu \mathrm{m}$ in $\mathrm{F}, \mathrm{G}$.

P14, fewer Purkinje cells express CCR1 (Fig. 7I), and at P21, when their dendritic trees have reached their full extent (see Fig. $4 \mathrm{D}_{3}$ ), no Purkinje cells are CCR1-positive (Fig. 7J). 
Figure $7 \mathrm{~K}$ and $\mathrm{L}$ focuses on the other CCR1-positive cell types within and near the PL at P14. Smaller, intensely immunoreactive cells in the PL are calbindin-negative (not shown) but display the characteristic GFAP-positive apical processes of Bergmann glia (Fig. 7K, arrows; $\mathrm{Z}$-series). Intense GFAP immunoreactivity is observed at the base of the radial fibers, adjacent to the CCR1-positive cell body (Fig. 7K, solid arrowheads). Juxtaposed with the radial fibers are GFAP-negative CCR1-positive cell bodies (Fig. 7K, open arrowheads). The CCR1-positive Bergmann glia are found directly between or below Purkinje cells (Fig. 7L) and have vertically oriented, oblong cell bodies (Fig. 7L, arrows). CCR1-positive cells with a rounded morphology are situated above the PL, at the PL/ML border, and are unassociated with GFAP-positive fibers (Fig. 7L, arrowhead). Most likely, these are the interneurons of the lower ML (basket cells; see below).

Figure 7M illustrates that at P21, CCR1-expressing cells are absent from the PL/ML border and are, instead, distributed throughout the ML $\left(\right.$ Fig. $\left.7 \mathrm{M}_{2}\right)$. Purkinje cells (Fig. 7M, arrowheads) are CCR1-negative but express MIP-1 $\alpha$ (Fig. $7 \mathrm{M}_{3}$ and $\mathrm{M}_{4}$, light blue color). The CCR1positive cells in the ML are closely associated with the dendrites of the MIP-1 $1 \alpha$-positive Purkinje cells (Fig. $7 \mathrm{M}_{2}$ and $\mathrm{M}_{4}$, arrows).

Doublecortin (DCx), a microtubule-associated protein, is expressed in migrating neurons (Gleeson et al., 1999). The rapidly changing distribution of CCR1 in the developing cerebellum (described above) prompted us to hypothesize that CCR1-expressing neurons also express DCx. However, we found no colocalization of DCx and CCR1. On $\mathrm{P} 14$, DCx immunoreactivity is concentrated in the postmitotic, differentiating zone of the EGL (EGLd; Fig. 7N), where little CCR1 is detected (Fig. 7N; see also Fig. 3A,B), and throughout the cytoplasmic spindles of NeuN-positive descending granule cells (Z-series; Fig. 7O).

At P21, numerous neurons with DCx-immunoreactive spindles are seen traversing the ML, in between CCR1positive interneurons (Fig. 7P); these descending NeuNpositive granule cells (Fig. $7 \mathrm{P}_{1}$, solid arrowheads) do not express CCR1 (Fig. 7P $\mathrm{P}_{2}$ ). CCR1-immunoreactive cells in the P21 ML are not immunoreactive for DCx or NeuN (Fig. 7P, open arrowheads). Based on the morphology of the CCR1-immunoreactive cells and given that the only cell bodies present in the P14/P21 ML are those of interneurons and descending granule cells (Altman and Bayer, 1997), we can conclude that the NeuN-negative, CCR1positive cell bodies in the P14 and P21 ML are interneurons.

\section{Summary}

Figure 8 graphically summarizes the developmental changes in the intensity and cell specificity of CCR1 expression in the cerebellum. The intensity of the shading corresponds with the overall intensity of CCR1 immunoreactivity in each cell population. CCR1 expression peaks transiently in both neuronal and non-neuronal cells and is completely absent from all cell types in the adult cerebellum except the granule cell.

\section{DISCUSSION}

These results demonstrate that CCR1 expression is developmentally regulated in both neurons and glia in the rat cerebellum. Our data also indicate that the CCR1 ligand MIP-1 $\alpha$ is expressed in white matter microglia and
Purkinje cells. Most notably, in the developing cerebellum, MIP-1 $\alpha$-immunoreactive cells are located near the cell bodies and processes of CCR1-expressing cells, specifically at times of neuronal and astrocytic maturation (see below). These findings suggest that CCR 1 and MIP-1 $\alpha$ may play a role in cerebellar development in the rat.

CCR1 mRNA was detected in cerebellum at all ages evaluated and was most abundant in adult brain, whereas CCR1 immunoreactivity peaked earlier, between P7 and P21. This finding suggests that CCR1 expression is posttranscriptionally regulated during postnatal cerebellar development.

\section{CCR1 immunohistochemistry in relation to neurite extension and cell maturation}

Neuronal maturation is characterized by neurite extension, acquisition of adult cellular morphology, and synaptogenesis. CCR1 immunoreactivity peaked transiently during neurite extension and maturation in granule cells (P10-P21), lower ML interneurons (basket cells; P15), upper ML interneurons (stellate cells; P21-P30), Purkinje cells (P7-P21), and Golgi cells (P14). CCR1 also peaked during the maturation of Bergmann glia (P12-P15) and astrocytes of the IGL (bushy astrocytes; P15) (Altman, 1972a-c; Altman and Bayer, 1997). Most of these cells were forming synapses or contacts with Purkinje dendrites or cell bodies during this phase. For example, the peak of CCR1 expression in Bergmann glia coincided with the so-called gliogenic phase (P12-P15), during which Bergmann glial fibers ensheath areas of mature synapses along Purkinje cell dendrites (Altman, 1972b). Interestingly, at the times of peak CCR1 immunoreactivity in most cell types, Purkinje cells were immunoreactive for MIP-1 $\alpha$.

In contrast, the peak immunoreactivity for CCR 1 in deep nucleus neurons (P7) did not directly coincide with neurite extension and maturation $\left[\mathrm{E}_{2} 2\right.$; (Altman and Bayer, 1997)]. Instead, peak CCR1 expression coincided with the maturation of afferent Purkinje axons [the formation of dense axonal fibrils, (Altman and Bayer, 1997)] and the initiation of MIP-1 $\alpha$ expression in Purkinje cell bodies.

\section{Intracellular CCR1 immunoreactivity}

In all CCR1-immunoreactive cell types, immunoreactivity was concentrated in the cytoplasm and the nucleus but was absent on cell processes. The cytoplasmic localization of chemokine receptors in neurons has been reported previously for CCR1, CCR3, CCR5, CXCR2, and CXCR4 (Hesselgesser et al., 1997; Bajetto et al., 1999; Klein et al., 1999; Boutet et al., 2001), and other authors have described "homogeneous cell staining" of chemokine receptors, closely resembling the combined cytoplasmic and nuclear CCR1 immunoreactivity we observed (Bajetto et al., 1999; Klein et al., 1999). Cytoplasmic localization may reflect ligand binding and internalization (Hesselgesser et al., 1998; Zhao et al., 1998) or concentration of newly synthesized protein within endoplasmic reticulum or Golgi compartments; nuclear localization suggests that this receptor may also have a role in intracellular signal transduction or protein trafficking.

Several studies have documented the concentration of chemokine receptors in neuronal processes (Klein et al., 1999; Boutet et al., 2001; Westmoreland et al., 2002). We did not detect CCR1 immunoreactivity on neuronal or astrocytic processes; however, we did observe punctate 

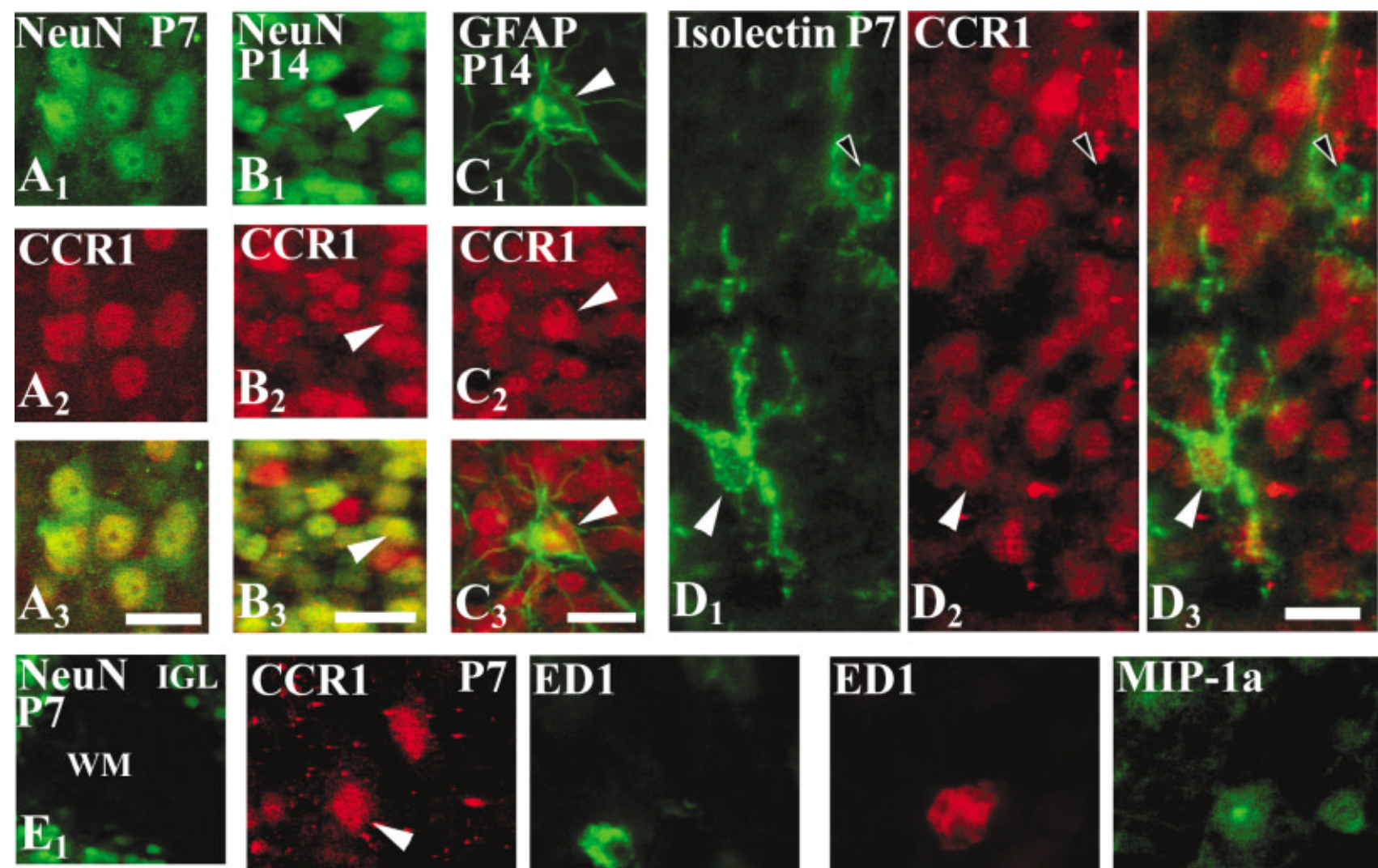

$\mathrm{C}_{3} \longrightarrow$

ED1

MIIP-1a
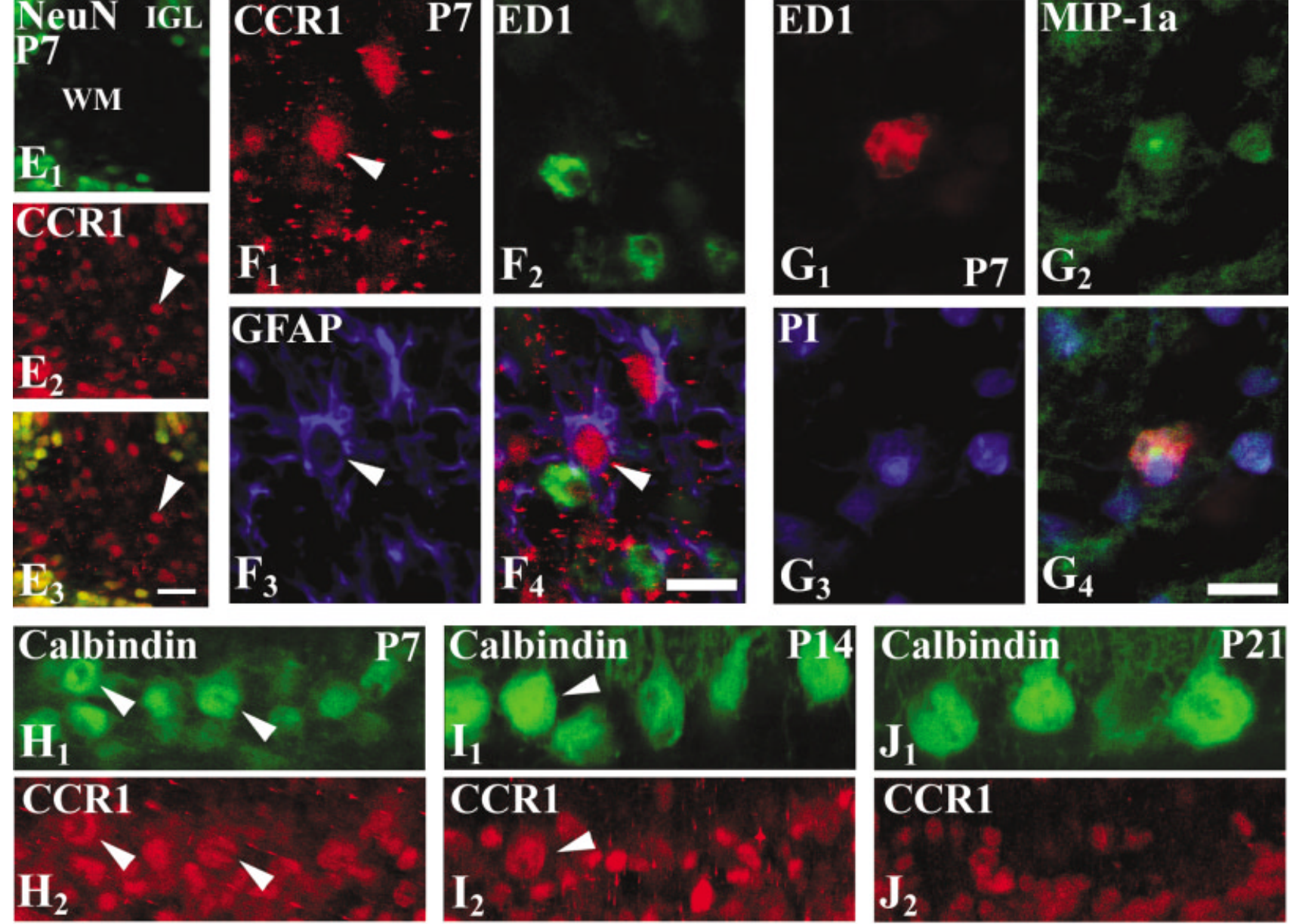

CCR1

$\mathbf{J}_{\mathbf{2}}$
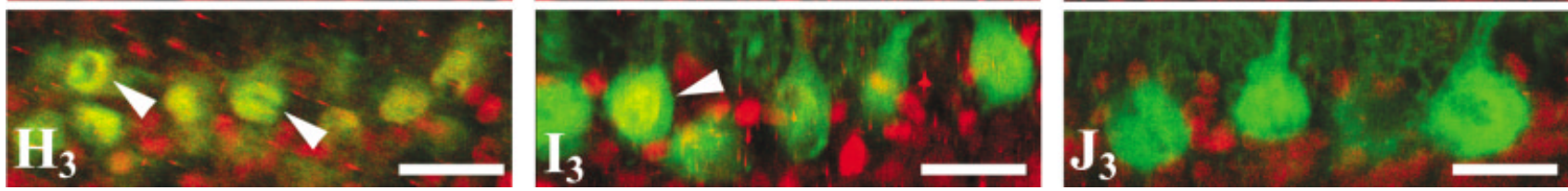

Figure 7 (Continued) 


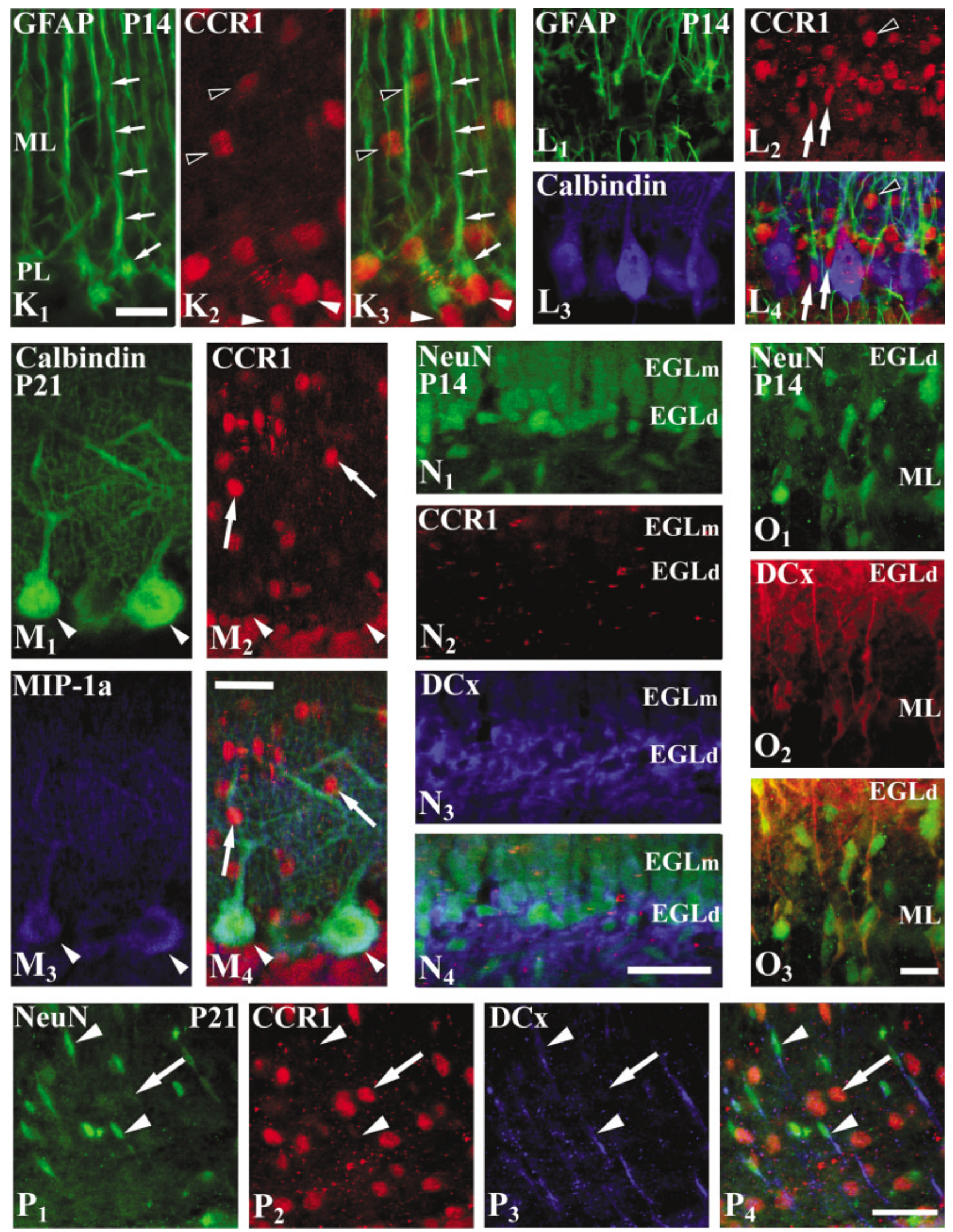


CCR1 immunostaining throughout the molecular layer, which could be attributable to receptors on parallel fibers or the neurites of basket, stellate, or Purkinje cells. Definitive localization of CCR1 to cell processes may require more sensitive methods such as immunoelectron microscopy.

\section{MIP-1 $\alpha$ immunoreactivity}

MIP- $1 \alpha$ immunoreactivity was detected in microglia in P7 and P14 cerebellar white matter and in Purkinje cells from P7 into adulthood. Physiologically activated (amoeboid) microglia are concentrated in normal developing white matter tracts and are involved in tissue remodeling and phagocytosis of dying cells. In P7 rat forebrain, activated microglia in white matter express MIP-1 $\alpha$, but these cells disappear by P12 (Cowell et al., 2002). In cerebellar white matter, however, MIP-1 $\alpha$-positive amoeboid microglia were identified at P7 and P14 (absent by P21). MIP-1 $\alpha$ expression was never localized to resting, white matter microglia; MIP- $1 \alpha$ expression may depend on the microglial activation state and/or the maturational phase of the surrounding white matter.

Purkinje cell MIP-1 $\alpha$ expression is a novel and unexpected finding. Reports of chemokine expression by neurons are scarce (Coughlan et al., 2000); however, Meng et al. (1999) documented the developmental expression of the closely related $\beta$-chemokine MCP-1 in Purkinje cells in late gestational human brain and hypothesized that MCP-1 is involved in Purkinje cell maturation. MIP-1 $\alpha$ immunoreactive Purkinje cells were observed in the vicinity of the cell bodies or processes of CCR1-expressing cells during development as well as in the adult, suggesting that CCR1 and MIP-1 $\alpha$ may have roles in normal cerebellar physiology.

Although MIP-1 $\alpha$ can stimulate increases in intracellular calcium via CCR1 in neurons in vitro (Meucci et al., 1998), it is not known whether neuronal MIP- $1 \alpha$ signaling via CCR1 occurs in vivo. CCR1 and MIP-1 $\alpha$ were expressed in the same neuroanatomical regions, whereas no immunoreactivity for another CCR1 ligand RANTES or the other main MIP- $1 \alpha$ receptor CCR5 was detectable in the cerebellum at any age. These observations suggest that MIP-1 $\alpha$ may be a functionally relevant ligand for CCR1 in the developing cerebellum.

\section{Function of CCR1 and MIP-1 $\alpha$ in the developing cerebellum}

There is strong evidence implicating the chemokine receptor CXCR4 in the regulation of neuronal migration in the mouse cerebellum; CXCR4 knockout (-/-) mice exhibit increased EGL thickness and abnormal granule cell positioning in early cerebellar development (Zou et al., 1998). In contrast, CCR1 immunostaining was absent from cells within the proliferating or premigratory zones of the EGL, migrating descending granule cells were rarely positive for CCR1, and few CCR1-immunoreactive cells expressed doublecortin, a protein specifically expressed in migrating neurons (Gleeson et al., 1999). Furthermore, preliminary evaluation of the cerebellar structure of adult CCR1 (-/-) mice with cresyl violet staining and light microscopy revealed no abnormalities (unpublished observations, RMC; mice generously provided by Dr. Craig Gerard, Harvard University). However, this observation does not exclude a role for CCR 1 in cerebellar development; there may be some degree of functional redundancy in this system that compensates for the lack of CCR1, resulting in a normal phenotype.

We speculate that CCR1 could influence maturationrelated processes such as neurite extension and cell adhesion. CCR1 is a G-protein-coupled receptor that, upon activation, initiates a complex cascade of intracellular events. In lymphocytes, MIP-1 $\alpha$ binding to CCR 1 activates the phosphatidyl inositol-3 kinase (PI3-K) and prolinerich tyrosine kinase/related focal adhesion tyrosine kinase
Fig. 7 (Overleaf). Cellular localization of CCR1 and MIP-1 $\alpha$ in cerebellum with confocal microscopy. Yellow color indicates colocalization of green and red labels. Light blue indicates colocalization of green and blue labels. Bright purple indicates colocalization of red and blue labels. Each panel set represents the fluorescent signal collected in a single confocal plane, unless otherwise specified. The final panel in each set is the composite of the preceding panels (i.e., $\mathrm{A}_{3}$ is the composite of $A_{1}$ and $A_{2}$ ). A: In the deep nucleus at P7, all NeuN-immunoreactive cell bodies are positive for CCR1. B: In the IGL at P14, many CCR1-positive cell bodies are immunopositive for the neuron-specific marker NeuN (arrowheads). C: In this same area, GFAP-positive astrocytes $\left(\mathrm{C}_{1}\right)$ have CCR1-positive cell bodies $\left(\mathrm{C}_{2}\right.$; arrowheads indicate the cell soma); colocalization was confirmed by the collection of fluorescence every $0.5 \mu \mathrm{m}$ through a thickness of 6.0 $\mu \mathrm{m}$ (Z-series), enabling the visualization GFAP-immunostained processes. D: In P14 IGL, some isolectin-reactive resting microglia with elaborate processes displayed immunoreactivity for CCR1 (solid arrowhead), whereas some did not (open arrowhead); $6.0 \mu \mathrm{m} \mathrm{Z}$-series. E: At P7, NeuN-labeled neurons of the IGL border the white matter (WM) in $\mathrm{E}_{1}$; numerous CCR1-positive cells are present in areas devoid of neurons (arrowheads, $\mathrm{E}_{2}, \mathrm{E}_{3}$ ). F: In P7 WM, CCR1 immunoreactivity does not colocalize with the microglial marker ED1 but is found on astrocyte cell bodies (arrowheads). G: In P7 WM, physiologically activated (ED1-positive) microglia $\left(\mathrm{G}_{1}\right)$ exhibit MIP-1 $\alpha$ immunoreactivity $\left(\mathrm{G}_{2}\right)$ concentrated adjacent to the cell nucleus, stained with the nucleic acid marker propidium iodide (PI; $\mathrm{G}_{3}$ ). H: In the PL on P7, CCR1 immunoreactivity colocalizes with the Purkinje cell marker calbindin (arrowheads). I: On P14, intense CCR1 immunoreactivity is occasionally present in Purkinje cell bodies (arrowhead). J: On P21, calbindin-positive Purkinje cells are no longer CCR1-immunoreactive but are bordered by smaller CCR1-positive cell bodies. K: In the PL on P14, CCR1-positive cell bodies (solid arrowheads, $\mathrm{K}_{2}, \mathrm{~K}_{3}$ ) have GFAPstained apical processes (arrows, $\mathrm{K}_{1}, \mathrm{~K}_{3}$ ), confirming their identity as Bergmann glia. Other CCR1-immunoreactive cell bodies are scattered in the ML (open arrowheads, $\mathrm{K}_{2}, \mathrm{~K}_{3}$ ) in a distribution similar to that of ML interneurons. Fluorescence was collected every $0.5 \mu \mathrm{m}$ through a thickness of $5.0 \mu \mathrm{m}$ for these images. L: Cells of different morphologies (vertically aligned and oblong, arrows; round, arrowheads) are present in the PL, closely apposed to calbindin-positive Purkinje cells. The oblong cells are associated with GFAP-positive apical processes, whereas the round cells are not. M: In P21 cerebellum, calbindinlabeled Purkinje cells (arrowheads, $\left.\mathrm{M}_{1}\right)$ no longer express CCR1 $\left(\mathrm{M}_{2}\right)$ but are immunoreactive for MIP-1 $\alpha\left(\mathrm{M}_{3}\right)$. CCR1-positive cells in the $\mathrm{ML}$ are closely associated with MIP-1 $\alpha$-positive Purkinje dendrites (arrows, $\left.\mathrm{M}_{2}, \mathrm{M}_{4}\right)$. N: Cells in the EGL are NeuN-positive $\left(\mathrm{N}_{1}\right)$ but CCR1-negative $\left(\mathrm{N}_{2}\right)$. Doublecortin $(\mathrm{DCx})$ is concentrated in the differentiating zone of the EGL (EGLd, $\left.\mathrm{N}_{3}\right)$, in NeuN-positive cells $\left(\mathrm{N}_{4}\right.$, light blue color). O: NeuN-immunoreactive cells in the $\mathrm{ML}\left(\mathrm{O}_{1}\right)$ have the morphology of descending granule cells and display DCx-positive spindles $\left(\mathrm{O}_{2}, \mathrm{O}_{3}\right)$. Fluorescence was captured from a 5.0- $\mu \mathrm{m}$ Z-series. P: On P21, NeuN-positive descending granule cells with DCximmunoreactive spindles are evident in the ML (solid arrowheads) interspersed with CCR1-positive cell bodies that are NeuN- and DCxnegative (open arrowheads). For abbreviations, see list. Scale bars = $20 \mu \mathrm{m}$ in $\mathrm{A}-\mathrm{C} ; 12.5 \mu \mathrm{m}$ in $\mathrm{D}, \mathrm{F}, \mathrm{G}, \mathrm{K} ; 50 \mu \mathrm{m}$ in E; $25 \mu \mathrm{m}$ in H-J,L-N,P; $10 \mu \mathrm{m}$ in $\mathrm{O}$. 
A.

Deep nucleus neurons
Purkinje cells
Granule cells (IGL)
Golgi cells
Lower ML interneurons
Upper ML interneurons

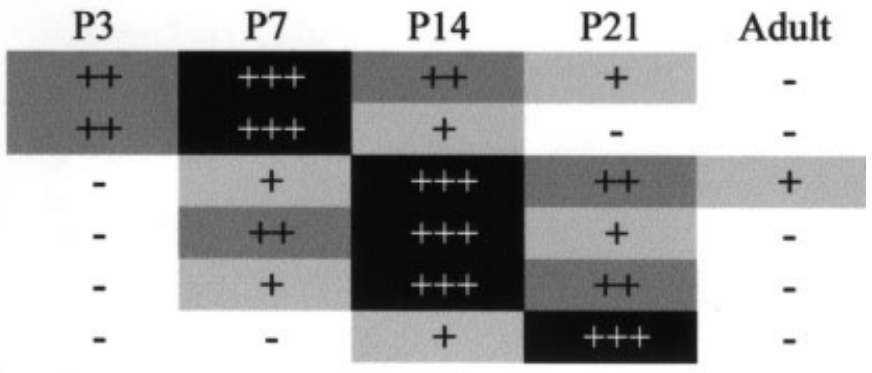

B.

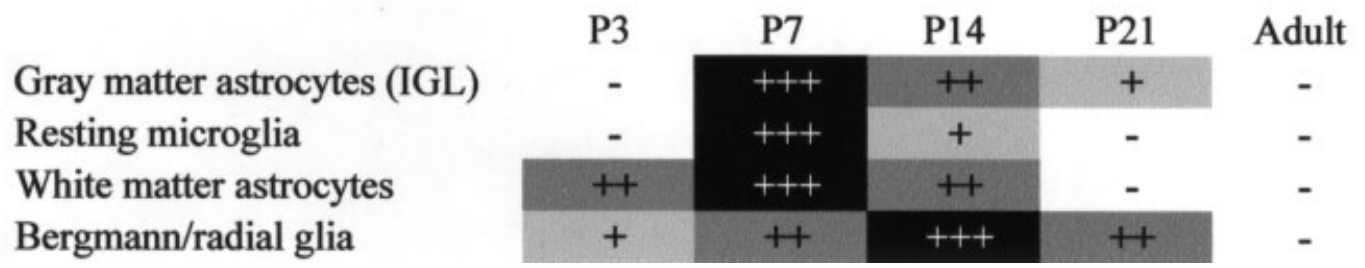

Fig. 8. Trends in CCR1 immunoreactivity in P3-adult cerebellum. CCR1-immunoreactive neurons (A) and glia (B) were identified by their location and morphology and/or by the colocalization of CCR1 with specific cell markers (confocal microscopy; see Materials and
Methods). The shading intensity represents the intensity of CCR1 immunoreactivity in the specified cell population. +++ , peak; ++ , intense; +, light; - , none.
(Pyk2/RAFTK) pathway, resulting in migration (Rumsey et al., 2001). However, in cerebellar neurons, activation of this pathway by growth factors induces differentiation, neurite and growth cone formation (Menegon et al., 1999; Ivankovic-Dikic et al., 2000; Park et al., 2000), and survival (Dudek et al., 1997). Of interest, the developmental and cell-specific expression of the PI3-K regulatory subunits p55 $\alpha$ and p55 $\gamma$ is similar to that of CCR1 (Trejo and Pons, 2001). p55 $\alpha$, in particular, is expressed by Purkinje cells early in development (P1) and basket cells later (P20).

Recently, Weber et al. (2001) demonstrated that CCR1 mediates leukocyte adhesion to capillary endothelium. Chemokine-mediated cell adhesion and membrane polarization (specialization) can also occur via the PI3-K pathway (Manes et al., 2000; Rodriguez-Frade et al., 2001), raising the possibility that chemokines may stimulate adhesion and membrane polarization in cerebellar neurons. In fact, there are marked similarities between the cerebellar distribution of CCR1 expression and the distributions of the synaptogenesis-related cell adhesion molecules Tyro-3 (Prieto et al., 2000), 2L4 (Wallis et al., 1992), and 5B4-cellular adhesion molecule (5B4-CAM) (Alcantara et al., 1992).

MIP-1 $\alpha$ binding to CCR1 can stimulate gene transcription and influence neuronal signaling as well (Miller and Oh, 2002). MIP-1 $\alpha$ induces transcriptional activation of the proto-oncogene $c$-fos in $\mathrm{T}$ cells by stimulating the translocation of signal transducer (STAT) to the nucleus (Wong and Fish, 1998), and MIP-1 $\alpha$-induced changes in intracellular calcium concentrations could strengthen nascent synapses and influence neurotransmitter release and neuronal survival in development (Giovannelli et al.,
1998; Mattson and Furukawa, 1998; Meucci et al., 1998; Kaul and Lipton, 1999; Klein et al., 1999).

CCR1 activation may have different functions in cerebellar glia, such as promoting migration, proliferation, and survival. At P7 and P14, CCR1-expressing astrocytes were located amidst MIP-1 $\alpha$-immunoreactive microglia in the cerebellar white matter. CCR1 activation may be particularly important in white matter at P7, when there is pronounced astrocyte proliferation (Zhang and Goldman, 1996) and programmed cell death (Krueger et al., 1995). In vitro, the CCR1 ligand RANTES promotes the survival of human fetal astrocytes (Bakhiet et al., 2001), and activation of the PI3-K/pyk2 pathway in astrocytes promotes DNA synthesis and proliferation (Cazaubon et al., 1997; Bajetto et al., 1999; Schinkmann et al., 2000). In addition, MIP- $1 \alpha$ can stimulate the migration of CCR1-bearing astrocytes in vitro (Tanabe et al., 1997); this may be relevant for astrocytes that migrate from their site of origin in the cerebellar white matter to the IGL (Zhang and Goldman, 1996).

There is growing recognition that intrauterine or perinatal infection can disrupt brain development. Analysis of CCR1 function and distribution in the developing cerebellum may elucidate a link between infection and cerebellar malformation. For example, infection of $\mathrm{P} 1$ rats with the Borna virus [as a model of autism (Pletnikov et al., 1999); for review, see Carbone et al., 2001] induces the upregulation of the CCR1 ligand RANTES in the cerebellum; the magnitude of chemokine expression correlates with the degree of motor learning impairment (Sauder et al., 2001). Also, injection of a polytropic murine retrovirus stimulates the production of RANTES and MIP-1 $\alpha$ in the neonatal mouse cerebellum, accompanied by the rapid onset 
of ataxia and seizures (Peterson et al., 2001). Overactivation of CCR1 may be responsible for the neuronal cell death and/or alterations in neurotransmission in these models (Hornig et al., 1999; Carbone et al., 2001).

The findings presented in this study support the hypothesis that chemokines and their receptors are involved in cerebellar development. Future studies will focus on determining the roles of specific chemokine/chemokine receptor pairs in development and neuropathology.

\section{ACKNOWLEDGMENTS}

We would thank Dr. Jack Parent for providing the doublecortin antibody, Haiyan $\mathrm{Xu}$ for technical support, and Dr. Roy Glover for critical review of the article.

\section{LITERATURE CITED}

Alcantara AA, Pfenninger KH, Greenough WT. 1992. 5B4-CAM expression parallels neurite outgrowth and synaptogenesis in the developing rat brain. J Comp Neurol 319:337-348.

Altman J. 1972a. Postnatal development of the cerebellar cortex in the rat. I. The external germinal layer and the transitional molecular layer. J Comp Neurol 145:353-397.

Altman J. 1972b. Postnatal development of the cerebellar cortex in the rat. II. Phases in the maturation of Purkinje cells and of the molecular layer. J Comp Neurol 145:399-463.

Altman J. 1972c. Postnatal development of the cerebellar cortex in the rat. III. Maturation of the components of the granular layer. J Comp Neurol $145: 465-513$.

Altman J, Bayer SA. 1997. Development of the cerebellar system: in relation to its evolution, structure and functions. Boca Raton: CRC Press.

Asensio VC, Campbell IL. 1999. Chemokines in the CNS: plurifunctional mediators in diverse states. Trends Neurosci 22:504-512.

Bajetto A, Bonavia R, Barbero S, Piccioli P, Costa A, Florio T, Schettini G. 1999. Glial and neuronal cells express functional chemokine receptor CXCR4 and its natural ligand stromal cell-derived factor 1. J Neurochem 73:2348-2357.

Bakhiet M, Tjernlund A, Mousa A, Gad A, Stromblad S, Kuziel WA, Seiger A, Andersson J. 2001. RANTES promotes growth and survival of human first-trimester forebrain astrocytes. Nat Cell Biol 3:150-157.

Balashov KE, Rottman JB, Weiner HL, Hancock WW. 1999. CCR5(+) and CXCR3(+) T cells are increased in multiple sclerosis and their ligands MIP-1lpha and IP-10 are expressed in demyelinating brain lesions. Proc Natl Acad Sci USA 96:6873-6878.

Boddeke EW, Meigel I, Frentzel S, Gourmala NG, Harrison JK, Buttini M, Spleiss O, Gebicke-Harter P. 1999. Cultured rat microglia express functional beta-chemokine receptors. J Neuroimmunol 98:176-184.

Boutet A, Salim H, Leclerc P, Tardieu M. 2001. Cellular expression of functional chemokine receptor CCR5 and CXCR4 in human embryonic neurons. Neurosci Lett 311:105-108.

Campbell IL, Abraham CR, Masliah E, Kemper P, Inglis JD, Oldstone MB, Mucke L. 1993. Neurologic disease induced in transgenic mice by cerebral overexpression of interleukin 6. Proc Natl Acad Sci USA 90:10061-10065.

Carbone KM, Rubin SA, Nishino Y, Pletnikov MV. 2001. Borna disease virus-induced neurobehavioral disease pathogenesis. Curr Opin Microbiol 4:467-475.

Cazaubon S, Chaverot N, Romero IA, Girault JA, Adamson P, Strosberg $\mathrm{AD}$, Couraud PO. 1997. Growth factor activity of endothelin-1 in primary astrocytes mediated by adhesion-dependent and -independent pathways. J Neurosci 17:6203-6212.

Chen SC, Leach MW, Chen Y, Cai XY, Sullivan L, Wiekowski M, DoveyHartman BJ, Zlotnik A, Lira SA. 2002. Central nervous system inflammation and neurological disease in transgenic mice expressing the $\mathrm{CC}$ chemokine CCL21 in oligodendrocytes. J Immunol 168:1009-1017.

Coughlan CM, McManus CM, Sharron M, Gao Z, Murphy D, Jaffer S, Choe W, Chen W, Hesselgesser J, Gaylord H, Kalyuzhny A, Lee VM, Wolf B, Doms RW, Kolson DL. 2000. Expression of multiple functional chemokine receptors and monocyte chemoattractant protein-1 in human neurons. Neuroscience 97:591-600.
Cowell RM, Xu H, Galasso JM, Silverstein FS. 2002. Hypoxic-ischemic injury induces macrophage inflammatory protein-1alpha expression in immature rat brain. Stroke 33:795-801.

Dudek H, Datta SR, Franke TF, Birnbaum MJ, Yao R, Cooper GM, Segal RA, Kaplan DR, Greenberg ME. 1997. Regulation of neuronal survival by the serine-threonine protein kinase Akt. Science 275:661-665.

Galasso JM, Miller MJ, Cowell RM, Harrison JK, Warren JS, Silverstein FS. 2000. Acute excitotoxic injury induces expression of monocyte chemoattractant protein-1 and its receptor, CCR2, in neonatal rat brain. Exp Neurol 165:295-305.

Gillard SE, Lu M, Mastracci RM, Miller RJ. 2002. Expression of functional chemokine receptors by rat cerebellar neurons. J Neuroimmunol 124: $16-28$.

Giovannelli A, Limatola C, Ragozzino D, Mileo AM, Ruggieri A, Ciotti MT, Mercanti D, Santoni A, Eusebi F. 1998. CXC chemokines interleukin-8 (IL-8) and growth-related gene product alpha (GROalpha) modulate Purkinje neuron activity in mouse cerebellum. J Neuroimmunol 92 122-132.

Gleeson JG, Lin PT, Flanagan LA, Walsh CA. 1999. Doublecortin is a microtubule-associated protein and is expressed widely by migrating neurons. Neuron 23:257-271.

Goldberg SH, van der Meer P, Hesselgesser J, Jaffer S, Kolson DL, Albright AV, Gonzalez-Scarano F, Lavi E. 2001. CXCR3 expression in human central nervous system diseases. Neuropathol Appl Neurobiol $27: 127-138$

Han Y, Wang J, Zhou Z, Ransohoff RM. 2000. TGFbeta1 selectively upregulates CCR1 expression in primary murine astrocytes. Glia 30:1-10.

Hesselgesser J, Horuk R. 1999. Chemokine and chemokine receptor expression in the central nervous system. J Neurovirol 5:13-26.

Hesselgesser J, Halks-Miller M, DelVecchio V, Peiper SC, Hoxie J, Kolson DL, Taub D, Horuk R. 1997. CD4-independent association between HIV-1 gp120 and CXCR4: functional chemokine receptors are expressed in human neurons. Curr Biol 7:112-121.

Hesselgesser J, Taub D, Baskar P, Greenberg M, Hoxie J, Kolson DL, Horuk R. 1998. Neuronal apoptosis induced by HIV-1 gp120 and the chemokine SDF-1 alpha is mediated by the chemokine receptor CXCR4. Curr Biol 8:595-598.

Hornig M, Weissenbock H, Horscroft N, Lipkin WI. 1999. An infectionbased model of neurodevelopmental damage. Proc Natl Acad Sci USA 96:12102-12107.

Horuk R, Martin AW, Wang Z, Schweitzer L, Gerassimides A, Guo H, Lu Z, Hesselgesser J, Perez HD, Kim J, Parker J, Hadley TJ, Peiper SC. 1997. Expression of chemokine receptors by subsets of neurons in the central nervous system. J Immunol 158:2882-2890.

Ivacko JA, Sun R, Silverstein FS. 1996. Hypoxic-ischemic brain injury induces an acute microglial reaction in perinatal rats. Pediatr Res 39:39-47.

Ivankovic-Dikic I, Gronroos E, Blaukat A, Barth BU, Dikic I. 2000. Pyk2 and FAK regulate neurite outgrowth induced by growth factors and integrins. Nat Cell Biol 2:574-581.

Johnston B, Burns AR, Suematsu M, Issekutz TB, Woodman RC, Kubes P. 1999. Chronic inflammation upregulates chemokine receptors and induces neutrophil migration to monocyte chemoattractant protein-1. $\mathrm{J}$ Clin Invest 103:1269-1276.

Kaul M, Lipton SA. 1999. Chemokines and activated macrophages in HIV gp120-induced neuronal apoptosis. Proc Natl Acad Sci USA 96:82128216.

Klein RS, Williams KC, Alvarez-Hernandez X, Westmoreland S, Force T, Lackner AA, Luster AD. 1999. Chemokine receptor expression and signaling in macaque and human fetal neurons and astrocytes: implications for the neuropathogenesis of AIDS. J Immunol 163:1636-1646.

Krueger BK, Burne JF, Raff MC. 1995. Evidence for large-scale astrocyte death in the developing cerebellum. J Neurosci 15:3366-3374.

Limatola C, Giovannelli A, Maggi L, Ragozzino D, Castellani L, Ciotti MT, Vacca F, Mercanti D, Santoni A, Eusebi F. 2000. SDF-1alpha-mediated modulation of synaptic transmission in rat cerebellum. Eur J Neurosci 12:2497-2504.

Locati M, Murphy PM. 1999. Chemokines and chemokine receptors: biology and clinical relevance in inflammation and AIDS. Annu Rev Med $50: 425-440$

Lore K, Sonnerborg A, Spetz AL, Andersson U, Andersson J. 1998. Erratum to "Immunocytochemical detection of cytokines and chemokines in Langerhans cells and in vitro derived dendritic cells" [corrected and republished article originally printed in J Immunol Methods 1998;214: 97-111]. J Immunol Methods 218:173-187. 
Ma Q, Jones D, Borghesani PR, Segal RA, Nagasawa T, Kishimoto T, Bronson RT, Springer TA. 1998. Impaired B-lymphopoiesis, myelopoiesis, and derailed cerebellar neuron migration in CXCR4- and SDF-1deficient mice. Proc Natl Acad Sci USA 95:9448-9453.

Manes S, Mira E, Gomez-Mouton C, Lacalle RA, Martinez C. 2000. Cells on the move: a dialogue between polarization and motility. IUBMB Life 49:89-96.

Mattson MP, Furukawa K. 1998. Signaling events regulating the neurodevelopmental triad. Glutamate and secreted forms of beta-amyloid precursor protein as examples. Perspect Dev Neurobiol 5:337-352.

Menegon A, Burgaya F, Baudot P, Dunlap DD, Girault JA, Valtorta F. 1999. FAK + and PYK2/CAKbeta, two related tyrosine kinases highly expressed in the central nervous system: similarities and differences in the expression pattern. Eur J Neurosci 11:3777-3788.

Meng SZ, Oka A, Takashima S. 1999. Developmental expression of monocyte chemoattractant protein-1 in the human cerebellum and brainstem. Brain Dev 21:30-35

Mennicken F, Maki R, de Souza EB, Quirion R. 1999. Chemokines and chemokine receptors in the CNS: a possible role in neuroinflammation and patterning. Trends Pharmacol Sci 20:73-78.

Meucci O, Fatatis A, Simen AA, Bushell TJ, Gray PW, Miller RJ. 1998. Chemokines regulate hippocampal neuronal signaling and gp120 neurotoxicity. Proc Natl Acad Sci USA 95:14500-14505.

Meucci O, Fatatis A, Simen AA, Miller RJ. 2000. Expression of CX3CR1 chemokine receptors on neurons and their role in neuronal survival. Proc Natl Acad Sci USA 97:8075-8080.

Miller RJ, Oh SB. 2002. Why do neurons express chemokine receptors? In: Ransohoff RM, editor. Universes in delicate balance: chemokines and the nervous system. New York: Elsevier. p 273-288.

Park SY, Avraham H, Avraham S. 2000. Characterization of the tyrosine kinases RAFTK/Pyk2 and FAK in nerve growth factor-induced neuronal differentiation. J Biol Chem 275:19768-19777.

Peterson KE, Robertson SJ, Portis JL, Chesebro B. 2001. Differences in cytokine and chemokine responses during neurological disease induced by polytropic murine retroviruses map to separate regions of the viral envelope gene. J Virol 75:2848-2856.

Pletnikov MV, Rubin SA, Vasudevan K, Moran TH, Carbone KM. 1999. Developmental brain injury associated with abnormal play behavior in neonatally Borna disease virus-infected Lewis rats: a model of autism. Behav Brain Res 100:43-50.

Prieto AL, Weber JL, Lai C. 2000. Expression of the receptor proteintyrosine kinases Tyro-3, Axl, and mer in the developing rat central nervous system. J Comp Neurol 425:295-314.

Rodriguez-Frade JM, Mellado M, Martinez AC. 2001. Chemokine receptor dimerization: two are better than one. Trends Immunol 22:612-617.

Rumsey LM, Teague RM, Benedict SH, Chan MA. 2001. MIP-1lpha induces activation of phosphatidylinositol-3 kinase that associates with Pyk-2 and is necessary for B-cell migration. Exp Cell Res 268:77-83.

Sauder C, Wolfer DP, Lipp HP, Staeheli P, Hausmann J. 2001. Learning deficits in mice with persistent Borna disease virus infection of the
CNS associated with elevated chemokine expression. Behav Brain Res 120:189-201.

Schinkmann KA, Kim TA, Avraham S. 2000. Glutamate-stimulated activation of DNA synthesis via mitogen-activated protein kinase in primary astrocytes: involvement of protein kinase $\mathrm{C}$ and related adhesion focal tyrosine kinase. J Neurochem 74:1931-1940.

Stanimirovic D, Satoh K. 2000. Inflammatory mediators of cerebral endothelium: a role in ischemic brain inflammation. Brain Pathol 10:113126.

Sugita Y, Zhao B, Shankar P, Dunbar CE, Doren S, Young HA, Schwartz JP. 1999. CNS interleukin-3 (IL-3) expression and neurological syndrome in antisense-IL-3 transgenic mice. J Neuropathol Exp Neurol 58:480-488.

Tanabe S, Heesen M, Berman MA, Fischer MB, Yoshizawa I, Luo Y, Dorf ME. 1997. Murine astrocytes express a functional chemokine receptor. J Neurosci 17:6522-6528.

Tani M, Fuentes ME, Peterson JW, Trapp BD, Durham SK, Loy JK, Bravo R, Ransohoff RM, Lira SA. 1996. Neutrophil infiltration, glial reaction, and neurological disease in transgenic mice expressing the chemokine N51/KC in oligodendrocytes. J Clin Invest 98:529-539.

Trejo JL, Pons S. 2001. Phosphatidylinositol-3-OH kinase regulatory subunits are differentially expressed during development of the rat cerebellum. J Neurobiol 47:39-50.

Van Der Meer P, Goldberg SH, Fung KM, Sharer LR, Gonzalez-Scarano F, Lavi E. 2001. Expression pattern of CXCR3, CXCR4, and CCR3 chemokine receptors in the developing human brain. J Neuropathol Exp Neurol 60:25-32.

Wallis I, Lasher RS, Ellis L, Siller K, Pfenninger KH. 1992. A developmentally regulated plasmalemmal antigen present in synaptosomes but not in growth cones. Brain Res Dev Brain Res 67:265-278.

Weber C, Weber KS, Klier C, Gu S, Wank R, Horuk R, Nelson PJ. 2001. Specialized roles of the chemokine receptors CCR1 and CCR5 in the recruitment of monocytes and $\mathrm{T}(\mathrm{H}) 1$-like/CD45RO $(+) \mathrm{T}$ cells. Blood 97:1144-1146.

Westmoreland SV, Alvarez X, deBakker C, Aye P, Wilson ML, Williams KC, Lackner AA. 2002. Developmental expression patterns of CCR5 and CXCR4 in the rhesus macaque brain. J Neuroimmunol 122:146158.

Wong M, Fish EN. 1998. RANTES and MIP-1lpha activate stats in T cells. J Biol Chem 273:309-314.

Xia MQ, Hyman BT. 1999. Chemokines/chemokine receptors in the central nervous system and Alzheimer's disease. J Neurovirol 5:32-41.

Zhang L, Goldman JE. 1996. Developmental fates and migratory pathways of dividing progenitors in the postnatal rat cerebellum. J Comp Neurol 370:536-550.

Zhao J, Ma L, Wu YL, Wang P, Hu W, Pei G. 1998. Chemokine receptor CCR5 functionally couples to inhibitory $G$ proteins and undergoes desensitization. J Cell Biochem 71:36-45.

Zou YR, Kottmann AH, Kuroda M, Taniuchi I, Littman DR. 1998. Function of the chemokine receptor CXCR4 in haematopoiesis and in cerebellar development. Nature 393:595-599. 